\title{
The Individual and the Public Service Enterprise in the New Industrial State
}

\author{
Matthew O. Tobriner* and Joseph R. Grodin**
}

$\mathrm{O}$ URS is a society of organization. It is a complex, interdependent society in which knowledge and function are exceedingly speciahzed and economic and political power highly centralized. The activities of government on all levels, the technology underlying the production and distribution of goods and services, and the control exercised by labor unions and professional societies-these constitute ever increasing aspects of contemporary social structure.

Such tendencies toward organization and specialization bear enormous significance for the individual in our society. They imply increased regulation of his behavior by both governmental and nongovernmental institutions, a relative decline in his control of institutional decisions affecting his existence, and a corresponding dependence upon group action for the expression of his political and economic interests. ${ }^{1}$ The impact of these phenomena is evident both in the extensive discussion by social scientists of the subject and in the popularity of phrases such as "technostructure," "organization man," and "alienation."

Given the dynamic nature of Anglo-American jurisprudence and its traditional concern for the individual, it is not surprising that such changes in social structure have been reflected at all levels of our legal system. ${ }^{3}$ Change is most obvious at the statutory level, where legislatures for a half century have focused on regulating enterprises and relationships to protect the individual in his role as a consumer, for example, or as an employee. ${ }^{4}$ Changes in constitutional law are also easy to discern. In-

* Associate Justice, California Suprene Court; A.B., 1924, Stanford University; M.A., 1925, Stanford University; LL.B., 1927, Harvard University; S.J.D., 1932, University of California. The authors wish to express appreciation to Barbara Brudno Rintala for her research assistance on this Article.

** B.A., 1951, University of California, Berkeley; LL.B., 1954 Yale University Law School; Ph.D., 1959, University of London; Member, California Bar.

1 For a discussion of some of these factors, see Latham, The Commonwealth of the Corporation, 55 Nw. U.L. REV. 25 (1960); Schwartz, Institutional Size and Individual Liberty: Authoritarian Aspects of Bigness, 55 Nw. U.L. REv. 4 (1960). For a sociological analysis of the effects of size and bureaucracy upon organizations and of the "iron law of bureaucracy," see R. Michers, Polttical Parties (1915).

2 See J. Galbratif, The New Industriat State (1967); D. Riesman, The Lonely Crowd (1960); W. Whrte, The Organdzation Man (1956).

3 See generally W. Friedrani, Law in a Changing Soctety (1959).

4 See generally B. Schwartz, A Commentary on the Constitution of the United States, Part 2, The Rights of Property (1965). 
creasing governmental involvement, for example, has blurred distinctions between things public and private and has led to expanded definitions of "state action," requiring application of due process and equal protection principles to seemingly private relationships. ${ }^{5}$ And within the area of constitutional application, there is a noticeable trend toward increased concern for the individual; ${ }^{6}$ witness, for example, recent decisions in the fields of welfare law, ${ }^{7}$ administrative law, ${ }^{8}$ and criminal law. ${ }^{\circ}$

Recognizing such broad legal change, this Article discusses only changes within the common law. Such changes are no more significant than those occurring at the statutory and constitutional levels. Quite the contrary, it is apparent that statutory change is far more pervasive and concededly more appropriate as a means of reflecting alterations in social conditions and public policy; shifts in constitutional doctrine are often more dramatic and more far-reaching in their impact. Moreover, discussion of common law trends is hazardous precisely because such trends are typically more subtle and therefore difficult to establish. We believe, however, that such common law trends are occurring in relation to the social changes mentioned earher and that explicit identification of these trends, where possible, is important to an understanding of the legal process.

We do not, of course, attempt here to examine the entire panorama of common law doctrines in relation to these elements of social change; even if our knowledge permitted us to engage in such a project, limitations of time and space would not. Rather, our Article is limited to exploration of one thesis for explaining only some aspects of the changes taking place. Our thesis, briefly stated, is that the common law responds in part to the challenges of organized society by reformulating common

5 See Burton v. Wilmington Parking Authority, 365 U.S. 715 (1961); Public Util. Comm'n v. Pollak, 343 U.S. 451 (1952); Horowitz, Fournteenth Amendment Aspects of Racial Discrimination in "Private" Housing, 52 CAITF. L. REv. 1 (1964); Van Alstyne \& Karst, Slate Action, 14 Stan. L. Rev. 3 (1961).

6 See generally Linde, Constitutional Rights in the Public Sector: Justice Douglas on Liberty in the Welfare State (pts. 1-2), 39 WasH. L. Rev. 4 (1964); 40 WaSH. L. REv. 10 (1965).

7 See Sherbert v. Verner, 374 U.S. 398 (1963) ; Parrish v. Civil Serv. Counn'n, 66 A.C. 253, 425 P.2d 223, 57 Cal. Rptr. 623 (1967); Syrek v. Unemployment Ins. Appeals Bd., 54 Cal. 2d 519, 354 P.2d 625, 7 Cal. Rptr. 97 (1960). See also O'Neil, Unconstitutional Conditions: Welfare Benefits with Strings Attached, 54 CALIF. L. REv. 443 (1966); Reich, Individual Rights and Social Welfare: the Emerging Legal Issues, 74 YaLE L.J. 1245-46 (1965).

8 See See v. City of Seattle, 387 U.S. 541 (1967); Camara v. Municipal Court, 387 U.S. 523 (1967); See also Schwartz, Crucial Areas in Administrative Law, 34 Geo. Wasm L. REV. 401 (1966).

- See Miranda v. Arizona, 384 U.S. 436 (1966); Malloy v. Hogan, 378 U.S. 1 (1964); Douglas v. California, 372 U.S. 353 (1963). See also Steaner, The Court and the Criminal, 8 WM: \& MARY L. REv. 319 (1967). For detailed discussion of one area, see Developments in the Law-Confessions, 79 HaRv. L. Rev. 935 (1966). 
law principles to impose duties and obligations on the basis of status or relationship, and that one such reformulation involves reviving early concepts of enterprises "affected with a public interest." We attempt to develop the thesis in the following pages. ${ }^{10}$

I

\section{STATUS CONCEPTS}

\section{A. Status Concepts and Early Law}

The society of the Middle Ages was relatively static. The feudal system and its agrarian economy produced a hierarchy of relationships and a degree of economic dependence whicl made both social and geographic mobility difficult, at least for the lower economic strata. An individual's "place" in society, i.e., his relationship with the establishment, basically was fixed by the circumstances of his birth.

Medieval common law reflected this fairly stable social order. Its principles rested heavily upon concepts of relationship or status; that is, it tended to posit rights and duties upon the relationship of parties within the socio-economic system rather than upon factors, such as consensual agreement, dependent on the will of individual litigants. ${ }^{11} \mathrm{We}$ inherit, in modified form, the law of landlord and tenant, master and servant, parent and child, and similar relationships, from that early period, which preceded modern development of contract and tort. ${ }^{12}$

The relationship at early common law between purveyors of goods and services and the consuming public was one of status, involving the concept of a "publc" or "common" calling or, to use a later phrase, an enterprise "affected with a public interest."13 Because such enterprises "held them-

${ }^{10} \mathrm{We}$ are by no means the first to point out the resurgence of status principles in modern law. For a classic early study see R. Pound, THE SpIRIT of the Conomon Law (1921), and for a more recent analysis see W. FrJEDMaNr, supra note 3. For a scholarly critique of Sir Henry Maine's classic thesis on status and contract, see Graveson, The Movement from Status to Contract, 4 MODERN L. REv. 261 (1941). An excellent sociolegal exploration of modern status principles is contained in P. Nonet, The Decline of Contract (1964) (unpublished M.A. thesis in University Library, University of California, Berkeley). These works present, however, a somewhat different focus than is the substance of our thesis.

11 See R. Pound, supra note 10 , at 20.

12 See id. at 22-25.

13 For discussion of the principle and its historical background, see $1 \mathrm{~B}$. Wraras, PUBLIC Service Corporations \$\$ 1-5 (1911); Arterburn, The Origin and First Test of Public Callings, 75 U. PA. L. Rev. 411 (1927); Burdick, The Origin of the Peculiar Duties of Public Service Companies, 11 CorUar. L. Rev. 514 (1911). See generally F. HaIr, THE CONCEPT of a Business Afrected witr a Public InTERest (1940). The phrase "affected with a public interest" was apparently coined by Sir Matthew Hale in 1676. A Treatise in Three Parts from a Mamuscript of Lord Chief Justice Hale, in A ColiecrIon of TRACTS ReIATTVE to the LAw of ENGLAND 1-248 (F. Hargrave ed. 1787). 
selves out" as providing a particular product or service to the community, the common law attached to them certain obligations, including-at various stages of doctrinal development-the duty to serve all customers on reasonable terms without discrimination and the duty to provide the kind of product or service reasonably to be expected from their economic role. ${ }^{14}$ Such occupations as blacksmith, ${ }^{15}$ food seller, ${ }^{16}$ veterinarian, ${ }^{17}$ and tailor, ${ }^{18}$ as well as those of common carrier ${ }^{19}$ and innkeeper, ${ }^{20}$ were probably included in that category. These obligations, imposed independently of consensual agreement or negligence, gradually took form in the doctrine of "general assumpsit," as distinguisled from "special assumpsit" which required a specific understanding or undertaking. ${ }^{21}$

14 The features which at early common law distinguished those engaged in public or common callings ... from those who were not so engaged, were the peculiar duties laid upon persons engaged in common callings to serve all applicants for their services, and to perform such services with care .... To these primary duties there are certain corollaries, namely that the service must be reasonably adequate and rendered upon reasonable terms, and that it must be impartial.

Burdick, supra note 13 , at 515 . It is likely that these various obligations arose over a period of time. F. Haxt, supra note 13 , at 12 .

15 "Note, that it was agreed by all the court that where a smith declines to shoe my horse, or an innkeeper refuses to give me entertainment at his inn, I shall have an action on the case, notwithstanding no act is done; for it does not sound in covenant." Anonymous, Keilway, 50, pl. 4 (K.B. 1450), reprinted in J. Beale \& B. Wraran, Cases on Public Service Companies 1 (1902).

16 "[A] victualler shall be compelled to sell his victual if the vendee las tendered him ready payment, otherwise not." Anonymous, Y.B. 10 Hen. 8, pl. 14 (C.P. 1494), reprinted in J. BEALE \& B. WyMAN, supra note 15, at 283.

17 Cf. Y.B. 19 Hen. VI 49, pl. 5 (C.P. 1441), reprinted in J. BeALE \& B. Wraran, stlpra note 15, at 1: "You have not shown that he is a common surgeon to cure such horses, and therefore, although he has killed your horse by his medicines you shall have no action against him without an assumpsit."

18 "I know well, if $I$ put a robe with a tailor to be made . . . in all cases of the sort I may have my robe lying in the tailor's shop as long as I please . . . for he is compelled by the law to do it, and he may by the law detain it until he is satisfied for the making." Anonymous, Y.B. 22 Edw. 4, 49, pl. 15 (1483), quoted in B. Wyacan, Public Service Corporattons $\$ 7$ (1911).

19 Jackson v. Rogers, 2 Shower 327 (K.B. 1683), reprinted in J. BEALE \& B. WXarar, supra note 15 at 1 .

20 See note 15 supra. For a general expression of the public service principle, see Lane v. Cotton, 12 Mod. Rep. 472, 484-85 (1701) (Holt, C.J.):

Wherever any subject takes upon himself a public trust for the benefit of the rest of his fellow-subjects, he is eo ipso bound to serve the subject in all the things that are within the reach and comprehension of such an office, under pain of an action against him .... If on the road a shoe fall off my horse, and I come to a smith to put one on, and the smith refuse to do it, an action will lie against him, because he has made a profession of a trade which is for the public good, and has thereby exposed and vested an interest of himself in all the king's subjects that will employ him in the way of his trade. (a) If an innkeeper refuse to entertain a guest where his house is not full, an action will lie against him.

21 The doctrinal relationships are a bit obscure. At early law, prior to the develop- 


\section{B. The Decline of Status}

With the advent of a mercantile economy and a liberal laissez-faire philosophy, status concepts yielded to doctrines like negligence and contract whicl were more appropriate to the encouragement of mobility and individual initiative because of their emphasis on the individual character of relationships. ${ }^{22}$ Contract, in particular, served to free individuals from static hierarchies and enabled them, through consent, to make law for themselves. Sir Henry Maine's statement that the evolution of law was from status to contract ${ }^{23}$ amounted to more than description; his famous dictum carried with it a judgment that progress lay in that direction. Contract became a principle vehicle of individualism in a free economy-the legal companion of economic and political liberalism. ${ }^{24}$

The concept of an enterprise "affected with a public interest" was eroded by the advent of the new system. With an increasing number of services available to the general public on a competitive basis, the concept of "holding out" lost distinctive significance, and so, while status concepts lingered in many areas of the common law, the obligations attached to a "public" calling survived only in a narrow category of enterprise, consisting principally of innkeepers and common carriers. ${ }^{25}$

\section{New Status Concepts}

The increased organization and specialization in modern society referred to earlier have created a gulf between social reality and the theoretical underpinnings of our legal doctrine. The theory, for example,

ment of modern tort and contract, liability through an action on the case could be imposed only when an "asumpsit" and the breach thereof were pleaded. Ames, The History of Assumpsit, 2 HARv. L. REv. 1, 3 (1888). Burdick, supra note 13, at 518-19, suggests that the obligations of a person engaged in a common calling were associated with assumpsit doctrine, but were implied from the lolding-out (a "general assumpsit") and did not have to be specially pleaded. Arterburn, supra note 13, at 416 , suggests that the obligations arose at an earlier date and grew out of the scarcity of labor caused by the Black Death. $B$. Wraraw, supra note 18 , at $\$ \S 1,35$, stresses the monopoly factor characteristic of enterprises said to be affected with a public interest. On this latter point, see also the development of labor union cases in text acconpanying notes 40-46 infra.

22 W. FrIEdManN, supra note 3, at 90, 127.

23 H. MaIne, Anchent Law 165 (F. Pollock ed. 1906).

24 See W. FrIEdManN, supra note 3, at 90-91.

$25 \mathrm{~F}$. HaLl, supra note 13, at 9-10. During the 1920's and 30's the concept of an enterprise "affected with a public interest" was briefly used for constitutional purposes, in a somewliat static and circular manner, to define and limit the kinds of businesses which legislatures could regulate without running afoul of substantive due process: that is, those businesses which had been traditionally regulated by common law before the constitution was adopted. See Tyson \& Brother v. Banton, 273 U.S. 418, 441 (1927). But gradually the Supreme Court widened the scope of legislative discretion until it held, in effect, that for constitutional purposes a business was affected with a public interest when a legislature said it was. See Nebbia v. New York, 291 U.S. 502 (1934). 
of a laissez-faire economy providing commodities competitively in response to consumer demands expressed through individual contracts bears little resemblance to the process by which a large-scale enterprise determines production and distribution. ${ }^{26}$ Nor does the ideal of individual mobihity entirely harmonize with the kinds of control exercised by trade unions and professional societies. This is not to criticize these aspects of our society; organization and technology inevitably affect the planning and distribution of goods and services, while unions and professional societies perforn an obviously desirable role. Moreover, it is no longer possible, even if it were desirable, to return to the society of the nineteenth century. Rather, we must recognize that in major areas of our social existence, theory does not match the facts of life. ${ }^{27}$

The discrepancy between theory and reality bears implications for many of our legal doctrines. Contract doctrine, for example, at one time the instrument of transition from status to individuahism, may today, if rigidly applied, produce a quite different result. Thus, an individual today does not bargain meaningfully over a union or professional society's constitution and bylaws, an automobile manufacturer's warranty, or an insurance policy. He accepts these as given; they are part of his economic environment. If they are contracts at all, they are "contracts of adhesion," ${ }^{28}$ imposed on a take-it-or-leave-it basis by the party possessing superior "bargaining" strength. Rigid rehance upon their terms as defining legal obligations between the parties may, in effect, produce new forms of subservience under the guise of contract. In such contexts contract law may be said to be undergoimg a functional revolution.

But if the law is to provide relief to the individual in such a situation despite or beyond agreements purportedly governing their relationshipand we believe the tendency of the law is in that direction-then status law may also be said to be undergoing a functional revolution. For, in such situations, statutory or judicial inposition of extra-contractual obligations to protect the individual is equivalent to the imposition of a new, legally created status in heu of that sought to be imposed by the dominant party. Thus, modern status principles may serve a vastly different func-

26 See J. Galbraith, The New Indostrtal State 23-26 (1967).

27 See id. at 8-9.

But, what is important is that this whole hody of [public service] law was a response to the felt needs of the times that spawned it. In our times, the interdependence of people has greatly increased; the days of laissez-faire have largely disappeared; men are more and more dependent on their neighbors for services as well as for housing and the other necessities of life.

Lombard v. Louisiana, 373 U.S. 267, 279 (1963) (concurring opinion of Douglas, J.). 28 See Isaacs, The Standardizing of Contracts, 27 YaLE L.J. 34 (1917); Kessler, Contracts of Adhesion-Some Thoughts about Freedom of Contract, 43 CoLUM. L. REv. 629 (1943); Patterson, The Interpretation and Construction of Contracts, 64 Corun. L. Rev. 833 (1964). 
tion from those of the feudal system. They cannot duplicate the functions originally served by contract, because that would require a drastic and impossible regression; the choice is not between feudalism and Victorian liberalism, but between a highly orgamized society with adequate protection for the individual and one without such protection.

We believe that our legal system is reviving status concepts-not from nostalgia for a bygone society, but to meet the cliallenges of today-and that one important aspect of that trend lies in the application to certain relationships of principles originating in the "public service" doctrine discussed above. In slort, certain institutions and enterprises are viewed by the courts as quasi-public in nature: ${ }^{29}$ The important products or services which these enterprises provide, their express or implied representations to the public concerning their products or services, their superior bargaining power, legislative recognition of their public aspect, or a combination of these factors, lead courts to impose on these enterprises obligations to the public and the individuals with whom they deal, ${ }^{30}$ reflecting the role which they have assumed, apart from and in some cases despite the existence of a contract. Sucli obligations flow from status rather than consensual relationships between the parties. In the pages which follow, we attempt to trace the modern development of the public service doctrine, first as applied to unions and professional societies througl judicial insistence upon open membership and fair treatınent, and then as applied to the relationslip between purveyors of goods and services and the consuming public, through insistence that the product or service conform to the reasonable expectations of the public.

Some words of caution before we begin: The concept of an enterprise

29 Characterization of an association or enterprise as "quasi-public" for purposes of applying common law status principles is to be distinguished from such a characterization for the purpose of applying constitutional "state action" concepts. The two are closely related, bowever, and may in some situations provide alternative means for reaching similar results. See the concurring opinions of Justice Douglas in Reitman v. Mulkey, 87 S. Ct. 1627, 1634-37 (1967), and Lombard v. Louisiana, 373 U.S. 267, 274-83 (1963); note 35 infra.

30 In the contexts referred to in this Article, "public" interest may be said to embrace the interests of the individuals involved in a particular relationship, in the sense that the public has an interest both in seeing that justice is done with respect to such individuals and in establishing a principle which will promote just results in other, similar situations. To the extent that the relationship is one which affects large numbers of the public, the overlap between private and public interests is obviously greater. In some contexts it is meaningful to speak of an imdependent public interest-for example, the public's interest in laaving access to qualified physicians is one which both coincides with and transcends the interests of applicants to medical societies-and in such cases we shall attempt to identify the separate interests involved. It is quite possible, of course, that specific public interests may conflict with individual interests in particular situations-for example, it is by no means clear that public interest in labor peace is served by incrcased membership participation within unions -but the cases we consider here are those in which courts bave found public interest and individual interests to be compatible. 
or institution affected with a public interest-we propose to call it a "public service" concept for short-is but one aspect of the larger field of status concepts. It is not in itself so mucli a rule of law as it is a tool of understanding, a metaplior, a way of explaining what courts are doing in a variety of situations. Althougl the criteria mentioned above ${ }^{31}$ appear to influence the judicial application of a public service concept, and various legal results appear to follow, our discussion shows that the relevance and weiglit of individual criteria and their impact upon the results depend heavily on the relationships and issues involved in particular fact situations. Moreover, the decisions we shall discuss can be and typically are explained by other legal concepts. The most we claim for our conception is that it is one way, and we believe a particularly helpful way, of lookmg at certain changes which have been taking place in our common law, of placing them in historical perspective, and thus of synthesizing what miglit otherwise be regarded as unrelated legal plienomena.

II

THE INDIVIDUAI AND THE ORGANIZATION

As economic and political power becomes channeled througl organizations, individuals become increasingly dependent upon membership and participation in such groups as unions, professional societies, and trade associations. ${ }^{32}$ Membership in these groups is often essential to effective

31 See text accompanying notes 29-30 supra.

32 Considerations of space have resulted in limiting the scope of this Article to the kinds of organizations listed and to their internal relationships with inembers and applicants for meinbership, although many other organizational relationships provide equally fertile areas for consideration of the public service concept. For discussion of the "quasi-public" nature of business corporations, see, e.g., Friedmann, Corporate Power, Government by Private Groups, and the Law, 57 CoLUM. L. REv. 155 (1957); Latham, supra note 1; Miller, The Corporation as a Private Government in the World Community, 46 VA. L. REv. 1539 (1960). On the relationship of corporations to shareholders, see F. EMrerson, SHaremorder DemrocRACY (1954). The relationship of umiversity to student also provides interesting analogies. See Seavey, Dismissal of Students: "Due Process," 70 Harv. L. Rzv. 1406 (1957); Van Alstyne, Procedural Due Process and State University Students, 10 U.C.L.A.I. Rev. 368 (1963); Symposium-Student Rights and Campus Rules, 54 CaIrF. L. REv. 1 (1966). For an carly study of the relationship of private groups to government, see Jaffe, Law Making $B y$ Private Groups, 51 HaRv. L. REv. 201 (1937).

We are able to touch only tangentially upon the collective bargaining relationship and labor arbitration, which represent a striking example of the intrusion of status concepts into the field of contract. Thus, the Supreme Court has said of the collective agreement that "it is more than a contract; it is a generalized code" to which "meaming and content" is given in the process of arbitration; the arbitrator's source of law "is not confined to the express provisions of the contract, as the industrial common law . . . is equally part of the collective agreement though not expressed in it." USW v. American Mfg. Co., 363 U.S. 564, 578, 581 (1960). See discussion in P. Nonet, supra note 10, at 61-74.

The relationship of organizations to the public generally (for example, consideration of the effect of a strike upon the public interest) presents different sorts of issues and is 
conduct of an individual's trade or profession, and, because of the economic and pohtical control exercised by such groups, participation in their affairs may be the only practical means an individual has of infiuencing his working environment. ${ }^{33}$ Whether or not it receives governmental sanction or recognition, ${ }^{34}$ the organization often becomes a kind of private government, effectively determining the conditions under which a trade or profession will be conducted..$^{35}$

Obviously, the individual has little effective bargaining power with such an organization. Absent legal assistance, he may be unable to gain admission or, once a member, may be denied effective participation in its affairs. The rules or policies which the organization adopts may affect him adversely in an arbitrary or discriminatory manner. Realistically viewed, the relationship is one of status rather than contract.

Such a relationship may be regarded as a "public" one because of various factors in which the public has a legitimate interest. Protecting the interests of the individuals affected is one public concern. Avoiding unreasonable restraints on the practice of a trade or profession which provides an important service or product to the public is another. Moreover, to the extent that the organization is either delegated public power ${ }^{36}$ or holds itself out as regulator or de facto spokesman for a trade or profession $^{37}$ the public has a legitimate interest in assuring that its ac-

likewise beyond the scope of this Article. Cf. Society of N.Y. Hosp. v. Hanson, 272 App. Div. 998, 73 N.Y.S.2d 835 (1947).

33 See generally Comment, Judicial Control of Actions of Private Associations, 76 HARv. L. REv. 983, 989 (1963). On the power of medical societies, see Comment, The American Medical Association: Power, Purpose, and Politics in Organized Medicine, 63 YaLE L.J. 937 (1954).

34 This is the case, for example, with a labor union granted exclusive status as bargaining representative by federal law. Labor Management Relations Act, 29 U.S.C. $\$ 159$ (a) (1964), and with a medical society empowered by state statute to appoint representatives to a state licensing board. See Comment, The American Medical Association: Power, Purpose, and Politics in Organized Medicine, 63 YaLE L.J. 937, 959 (1954).

35 The similarity between such organizations and government, both with respect to function and structure, often leads courts to apply rules derived from constitutional principles. See text accompanying notes 64-71 infra, and the more detailed discussion in J. Grodiv, Union Governarent AND THE LAW 90 (1961). The governmental analogy is to be distinguished from the proposition that an organization may be so infused with governmental involvement (through licensing, delegation of authority, monopoly status, etc.) that its actions become actions of the state, warranting the direct application of constitutional principles. E.g., Smith v. Allwright, 321 U.S. 649 (1944); see Comment, Judicial Control of Actions of Private Associations, 76 HARv. L. REv. 983, 1055 (1963) ; cf. Oliphant v. Brotherlood of Locomotive Firemen, 262 F.2d 359 (6th Cir. 1958), cert. denied, 359 U.S. 935 (1959).

36 See note 34 supra.

37 A real estate board, for example, may represent in its advertising to the public that it includes "ethical" realtors, and that it polices its own members with respect to ethics. That was the situation in the cases cited in note 53 infra. The situation is similar with respect to medical societies. See Comment, supra note 34, at 962-76. 
tions are reasonably representative of the trade or profession involved and that it does not act arbitrarily or discriminately with respect to members or applicants.

The kinds of organizations we are describing thus often meet all of the criteria of public service status referred to in the preceding section. It is not surprising, therefore, that courts have tended in recent years to impose obhigations designed to protect the individual and public interests involved.

Traditionally, trade and professional groups were assimilated to clubs and fraternal societies for purposes of common law rules dictating a high degree of judicial abstention from the internal affairs of nonprofit "voluntary associations." 38 Accordingly, the membership policies of sucl associations were their own affair; once admitted to membership, an individual's relationship with his organization was himited by the group's own rules, viewed as a contract. ${ }^{39}$ This wall of abstention, based as it was on judicial reluctance to become embroiled in the affairs of organizations such as cliurcl groups and fraternal societies and bearing little relationship to the developing facts of life concerning trade and professional societies, was destined to yield to the tides of change.

\section{A. Admission of Members to Labor Unions}

The most noticeable departure from a policy of judicial abstention occurred in cases involving admission to labor unions, in which the principles developed bore striking resemblance to earlier concepts of an enterprise affected with a public interest. ${ }^{40}$ Courts began to say that a union could not enter into closed shop agreements requiring membership as a condition of employment and at the same time maintain an arbitrarily closed union. The situation was analogized to that of a business affected with a public interest at common law. Thus, the New Jersey Court of Chancery in an early case said:

[M]onopoly raises duties which may be enforced against the possessors of the monopoly. This has been recognized from the earliest times. The rule that one who pursued a common calling was obliged to serve all comers on reasonable terms, seems to have been based on the fact that innkeepers, carriers, farriers, and the like, were few, and each had a virtual monopoly in his neighborhood. . . . The question presented in the instant case is not one of prices or of serving the public but one of employment .... However, the principle is the same;

38 The classic description of this judicial attitude is contained in Chafee, The Internal Affairs of Associations Not For Profit, 43 HARv. L. REv. 993 (1930).

39 Id. at 1001.

40 For more detailed discussion of the development, see Summers, Union Powers and Workers' Rights, 49 Micr. L. REv. 805 (1951); Summers, The Right to Join a Ution, 47 COLUM. L. REV. 33 (1947). 
the holders of the monopoly must not exercise their power in an arbitrary, unreasonable manner so as to bring injury to others. ${ }^{41}$

Six years later, in James v. Marinship Corporation, ${ }^{42}$ the California supreme court adopted similar reasoning to enjoin the Boilermakers' Union from simultaneously enforcing a closed slop policy and a requirement that Negro workers belong to a separate "auxiliary" union which allowed them no voice in determining the officers or policies of their bargaining representative. Drawing on the New Jersey case, Justice Gibson said:

In our opinion, an arbitrarily closed or partially closed union is incompatible with a closed shop. Where a union has, as in this case, attained monopoly of the supply of labor by means of closed shop agreements and other forms of collective labor action, such $a$ union occupies a quasi-public position similar to that of a public service business and it has certain corresponding obligations. It may no longer claim the same freedom from legal restraint enjoyed by golf clubs or fraternal associations. Its asserted right to choose its own members does not merely relate to social relations; it affects the fnndamental right to work for a living. ${ }^{43}$

While Marinship was based on a finding that the union, through closed shop agreements with local employers, had effected monopoly control, existence of such a broad monopoly subsequently was held not to be necessary where the union controlled jobs with a particular employer. ${ }^{44}$ Still later, the Cahforma court held in effect that even job control was not essential; in Thorman v. International Alliance of Theatrical Stage Employees $\mathcal{E}^{\circ}$ Moving Picture Machine Operators ${ }^{45}$ it ordered a union to admit an apphicant found by the court to have been arbitrarily excluded from membership without affording the union the alternative, provided for in Marinship, of modifying its closed shop pohcy.

The Thorman decision thus tacitly protected the applicant's interest in participating in union affairs, quite apart from his interest in job acquisition or retention. Recently the California court gave express recognition to the doctrime imphed in Thorman:

41 Wilson v. Newspaper \& Mail Deliverers' Union, 123 N.J. Eq. 347, 350-51, 197 A. 720, 722 (Ch. 1938).

4225 Cal. 2d 721, 155 P.2d 329 (1944).

43 Id. at 731, 155 P.2d at 335 (emphasis added).

44 E.g., Williams v. International Bhd. of Boilermakers, 27 Cal. 2d 629, 165 P.2d 903 (1946). The rule was also extended to prohibit discrimination for arbitrary reasons other than race. E.g., Bautista v. Jones, 25 Cal. 2d 746, 155 P.2d 343 (1944) (independent peddlers); Riviello v. Journeymen Barbers' Union, 88 Cal. App. 2d 499, 199 P.2d 400 (1948) (self-employed barber); Thorman v. International Alliance etc. Eniployees, 49 Cal. 2d 629,320 P.2d 494 (1958) (failure to win menıbership approval).

4549 Cal. 2d 629, 320 P.2d 494 (1958). 
The decisions of this court thus recognize that membership in the union means more than mere personal or social accommodation. Such membership affords to the employee not only the opportunity to participate in the negotiation of the contract governing his employment but also the chance to engage in the institutional life of the union. ... .

... Participation in the union's affairs by the workman compares to the participation of the citizen in the affairs of his community. The union, as a kind of public service institution, affords to its members the opportunity to record themselves upon all matters affecting their relationships with the employer; it serves hikewise as a vehicle for the expression of the membership's position on political and community issues. . . 46

Thus, regardless of the particular union's nature or agreement with its members, certain obligations may be imposed on it as a "public service" institution.

\section{B. Admission of Members to Other Organizations}

Extension of the Marinship doctrine to other types of organization has been slow, but the trend is clearly in that direction. ${ }^{47}$ One of the first cases to apply the doctrine outside the labor field was Falcone $v$. County Medical Society, ${ }^{48}$ in which the Supreme Court of New Jersey ruled that, in view of both a medical society's de facto control over access by physicians to hospitals and the public's concern over the practice of medicine, the society's power to exclude applicants for membership "should not be unbridled but should be viewed judicially as a fiduciary power to be exercised in a reasonable and lawful inanner for the advancement of the imterests of the medical profession and the public generally."49

Dr. Falcone, holding a Doctor of Osteopathy degree from an American college, received a Doctor of Medicine degree from the AMAapproved University of Milan on the basis of only seven months attendance plus credit for his previous studies. The medical society sought to exclude him because his New Jersey license to practice medicine made reference only to his osteopathy degree, and therefore, the society argued, he was not actually hicensed to practice medicine. Moreover, the society had an "unwritten" rule requiring four years attendance at an AMAapproved institution. The court held the first ground "unsound" because his license authorized him to practice medicine and surgery without re-

46 Directors Guild of America, Inc. v. Superior Court, 64 Cal. 2d 42, 52-53, 409 P.2d 934, 941-42, 48 Cal. Rptr. 710, 717-18 (1966).

47 For a more detailed discussion of the law in this area, see Comment, Judicial Control of Actions of Private Associations, 76 HARv. L. REv. 983 (1963).

4834 N.J. 582, 170 A.2d 791 (1961).

$49 \mathrm{Id}$. at $597,170 \mathrm{~A} .2 \mathrm{~d}$ at 799. 
striction; it found application of the unwritten rule in the circumstances to be "patently arbitrary and unreasonable and beyond the pale of the law." public and the medical profession, it could not act arbitrarily in admitting members. The court therefore affirmed judgment requiring the society to admit Dr. Falcone to full membership.

Similar principles have been applied to other cases dealing with the admission of physicians to medical societies ${ }^{51}$ and hospital staffs. ${ }^{52}$ Two California trial courts have held that a local real estate board which controls multiple listing services and holds itself out to the public as a regulator of the industry is "affected with a public interest" and may not arbitrarily or unreasonably exclude licensed brokers from membership. ${ }^{53}$ Similar limitations liave been recognized as applicable to other professional societies in cases wherein relief is nevertheless denied on facts slowing the exclusion was not arbitrary or unreasonable..$^{54}$

In determining whether good cause exists for exclusion of an applicant, courts have considered the interests of both the applicant and the public. The factors wlich courts deem relevant in determining whether good cause exists indicate the "public service" nature of the institution involved and the extent to whicl broad policies rather than individual agreements may be used to determine the obligations of the parties. As the Arizona supreme court said in a case involving admission to a medical society:

When determining whether "just cause" has been shown, the court must consider whether the grounds for exclusion were (1) supported by substantial evidence and (2) reasonably related to legitimate professional purposes of the Society. The judicial process involved in determining such a standard of reasonableness is essentially one of balancing individual, group, and public interests: the riglit of the individual to practice his profession without undue restric-

50 Id. at 598,170 A.2d at 800 .

51 Blende v. County Medical Soc'y, 96 Ariz. 240, 393 P.2d 926 (1964); Kurk v. Medical Soc'y, 46 Misc. 2d 790, 260 N.Y.S.2d 520 (Sup. Ct. 1965). See Note, Expulsion and Exchusion from Hospital Practice and Organized Medical Societies, 15 RUTGERS L. Rev. 327 (1961); Comment, The American Medical Association: Power, Purpose, and Politics in Organized Medicine, 63 YALE L.J. 937 (1954).

52 E.g., Rosner v. Township Hosp. Dist., 58 Cal. 2d 592, 375 P.2d 431, 25 Cal. Rptr. 551 (1962); Greisman v. Newcomb Hosp., 40 N.J. 389, 192 A.2d 817 (1963).

53 Slaughter v. Board of Realtors, No. 334342 (Super. Ct., Alameda County, Calif., Mar. 29, 1965) ; Martin v. Board of Realtors, No. R-12694 (Super. Ct., Contra Costa County, Calif., May 16, 1966).

54 E.g., Kronen v. Pacific Coast Soc'y of Orthodontists, 237 Cal. App. 2d 289, 46 Cal. Rptr. 808 (1965). Cf. Salter v. State Psychological Ass'n, 14 N.Y.2d 100, 198 N.E.2d 250 (1964). Various trade associations have also been subjected to judicial scrutiny with respect to their admissions policies, but here courts have relied principally upon antitrust statutes rather than common law. See Comment, supra note 47, at 1042. 
tion; the right of the public to have unrestricted choice of physicians; and the justification for the Society's action. When examining the justification for the exclusion, the court slould consider several factors: the social value of the Society's action; the appropriateness of the society as a means of achieving the goal; and the reasonableness of this particular action of the Society in relation to the goal.55

While cautioning against de novo review by the court of factual matters involving the special competence of the society, the Arizona court indicated that the applicant was entitled to consideration of his application in "proceedings embodying the elements of due process."

\section{Protection of Organization Members Against Arbitrary Action}

Protection of the individual against arbitrary action by organizations once he is a member is an area of law wlich, again, the courts pioneered in dealing with labor unions. While the relationship between unions and their members is now regulated extensively by statute, ${ }^{67}$ the statutes themselves are mainly codifications of leading common law decisions. ${ }^{58}$ The pattern of these decisions represents a striking instance of the manner in which courts in appropriate situations cut through traditional contract principles to establish rights and obligations based on relationship, or status.

The doctrine that a member is entitled to a fair hearing before he is expelled, suspended, or otherwise disciplined by his union is one example. The fair hearing requirement was first established in early cases involving religious and fraternal societies; ${ }^{59}$ and, although the basis of the requirement was not then discussed, it was later regarded as an implied term of the "contract" which the organization's rules created between the society and each member or among its members. ${ }^{60}$ If the rules expressly dispensed with a hearing, however, or provided specifically for a type of hearing not consistent with generally accepted notions of fairness, the court could not read im such an implied term. Under strict contract theory, the court would be powerless to interfere, since even invalidation of obnoxious clauses as contrary to public policy would not produce an affirmative fair hearing requirement. ${ }^{01}$

\footnotetext{
55 Blende v. County Medical Soc'y, 96 Ariz. 240, 245, 393 P.2d 926, 930 (1964).

$58 I d$.

57 Labor Management Reporting and Disclosure Act of 1959, 29 U.S.C. $\$ 401$ (1964). There is also a considerable degree of state legislation in the field. See Aaron \& Komaroff, Statutory Regulation of Internal Union Afairs, 44 Irx. I. REv. 425 (1949); Katz, Two Decades of State Labor Legislation: 1937-1958, 25 U. Cm. L. Rev. 109 (1957).

58 See J. Grodin, supra note 35; Cox, The Role of Law in Preserving Union Democracy, 72 Harv. L. Rev., 609 (1959); Summers, The Role of Legislation in Internal Union Affairs, 10 LAB. L.J. 155 (1959).

59 E.g., Innes v. Wylie, 174 Eng. Rep. 800 (Q.B. 1884) (club).

60 Maclean v. Workers Union, [1929] 1 Ch. 602.

61 Id.
} 
Nevertheless, some courts at common law came to rule, in more recent union cases, that a fair hearing was required whatever the union's rules might say on the subject. ${ }^{62}$ The considerations behind such a requirement were expressed as follows by an Enghish jurist:

$[T]$ hese rules are more a contract in theory than a contract in fact. In order for there to be a true contract, there inust be the agreement of parties freely made with full knowledge and without any feehng of constraint. ... In order that a person should be allowed to work at his trade he had to sign a document agreeing to the rules. He had no option but to sign. . . .

... [R]ules ... applied to a man in that state of mind ... are not so much a contract, as we used to understand a contract, but they are much more a legislative code laid down by some members of the union to be imposed on all members of the union. They are more like by-laws than a contract. ${ }^{63}$

In other words, union bylaws, viewed as a contract, constitute a contract of adhesion which is in reality a form of status, and courts confronted with such a relationship will not permit the terms of the contract to negate requirements which they consider clearly required by public policy to protect the individual.

Judicial limitations on grounds for union discipline also reflect concern with both the nature of the union as an institution and the union's relationship to its individual members without regard to contractual requirements. In general, courts have imposed upon unions, as a matter of common law, limitations derived by analogy from constitutional principles on the basis of a recognition, not always expressed, that a union is a "quasi-governmental" organization. ${ }^{64}$ Thus, in addition to requiring due process in disciplinary proceedings, courts have prevented unions from disciplining members who criticize union officers and policies, ${ }^{65}$ or who, as citizens, voice political opmions, ${ }^{66}$ vote, ${ }^{67}$ or testify ${ }^{68}$ contrary

62 E.g., Bricklayers Union v. Bowen, 183 N.Y.S. 855 (Sup. Ct. Eq. T. 1920), aff'd without opinion, 198 App. Div. 967, 189 N.Y.S. 938 (1921).

03 Bonsor v. Musicians Union [1954] Ch. 479, 485 (Denning, L.J.).

64 See note 35 supra.

65 E.g., Madden v. Atkins, 4 N.Y.2d 283, 151 N.E.2d 73, 174 N.Y.S.2d 633 (1958); Crossen v. Duffy, 90 Ohio App. 252, 103 N.E.2d 769 (1951). For analysis of the case results, showing protection of free expression both explicitly and implicitly, see Sumners, The Political Liberties of Labor Union Members, 33 TExAs L. REv. 603 (1955).

66 E.g., Mitchell v. International Ass'n of Machinists, 196 Cal. App. 2d 796, 16 Cal. Rptr. 813 (1961) (campaigning in favor of right-to-work law); Spayd v. Ringing Rock Lodge, 270 Pa. 67, $113 \mathrm{~A}$. 70 (1921) (petitioning legislature in opposition to bill which union supported).

67 Schneider v. Local 60, $116 \mathrm{La} .270,40$ So. 700 (1905) (failure to obey union's instructions to vote as a member of a municipal board of examiners for particular candidate as plumbing inspector).

${ }^{68}$ Abdon v. Wallace, 95 Ind. App. 604, 165 N.E. 68 (1929) (testifying before a legislative committee that particular railroad equipment, favored by the union, had certain disadvantages). 
to the wishes of the union. Unions may not make rules creating arbitrary or unreasonable classes of membership, ${ }^{60}$ and, in dealing with employers, they nuust represent employees in the bargaining unit fairly, without discrimination, ${ }^{70}$ and perhaps with reasonable diligence. ${ }^{71}$ In effect, courts have decreed that the union-member relationship, whatever the union's rules, is to be treated in many respects like the relationship between a government and a citizen.

Some of these principles, hike the rules on admission to membership, have been applied to other organizations which ineet the "public service" criteria. Presumably a member of any professional association in which membership is important to the practice of his profession or trade is entitled as a matter of law to a fair hearing in disciphnary proceedings against him. ${ }^{72}$ Courts have imposed similar limitations on grounds for disciplinary action. For example, in one California case, a physician was expelled from his local medical society on the charge, among others, that he had made "disparaging" comments about a fellow physician in a report to the Industrial Accident Commission. Applying precedent from labor union cases, the court held that interpretation of the Association's bylaws to allow discipline for such conduct would contravene public policy. ${ }^{73}$

The organizations referred to in this section are obviously diverse in their economic and social settings, and each requires individual treatment beyond the scope of this Article. But through the cases there runs a common thread of thought, sometimes express, but most often imphicit: Each of these organizations plays a more or less definable role in our society, and the legal content of the relationships involved is molded in part by the nature of that role, by the appropriateness of particular

69 E.g., Cameron v. International Alliance etc. Employees, 118 N.J. Eq. 11, 176 A. 692 (Ct. Err. \& App. 1935).

70 Steele v. Louisville \& N.R.R., 323 U.S. 192 (1944). Here, however, the derivation of the requirement is mainly statutory. For discussion, see Cox, The Duty of Fair Representation, 2 VIII. L. REv. 151 (1957); Wellington, Union Democracy and Fair Representation: Federal Responsibility in a Federal System, 67 YALE L.J. 1327 (1958).

71 See Glover v. Brotherhood of Ry. \& S.S. Clerks, 250 N.C. 35, 108 S.E.2d 78 (1959) (common law suit based on negligence and agency). Cf. Vaca v. Sipes, 386 U.S. 171 (1967) (no violation of duty of fair representation under federal law for union to refuse to process grievance on basis of good faith, though erroneous, behef that grievance was without merit).

72 E.g., Swital v. Real Estate Comm'r, 116 Cal. App. 2d 677, 254 P.2d 587 (1953); Virgin v. American College of Surgeons, 42 Ill. App. 2d 352, 192 N.E.2d 414 (1963); Berberian v. Osteopathic Hosp. Ass'n, 395 Pa. 257, 149 A.2d 456 (1959). See Annot., Suspension or Expulsion from Professional Associations, 20 A.L.R.2d 531 (1951).

73 Bernstein v. Medical Ass'n, 139 Cal. App. 2d 241, 293 P.2d 862 (1956). The case was remanded to the Association's trial council for determination of penalties on the remaining charges. Cf. State ex rel. Waring v. Medical Soc'y, 38 Ga, 608 (1869) (invahidating discipline for providing bond to Negro); Manning v. Klein, 1 Pa. Super. 210 (1896) (discipline for joining Sunday closing committee). 
actions and policies to that role, and by the reasonable expectations of the public and the individuals affected. Such factors are neither abstractly determined nor static in nature but are derived from examination of the life and dynamics of the organization itself and from its own definition of its role expressed through its rules and customs. The nature and extent of judicial intervention should be, and normally is, himited by considerations of organizational autonomy, through, for example, the doctrine requiring exhaustion of internal remedies. ${ }^{74}$ But judicial recognition of all these considerations goes beyond rehance on traditional concepts of contract and tort, and to that extent it represents a recognition and imposition of status concepts. We turn now to other relationships, less organizational in structure, which we believe generate similar concepts and judicial attitudes.

\section{III \\ THE INDIVIDUAL AND THE PRIVATE ENTERPRISE}

The relationship between the individual consumer and a business enterprise is quite different in a number of significant respects from the organizational relationships previously discussed. It is typically a sporadic rather than a continuing relationship, and for that reason some of the considerations which underlie status concepts are less applicable. ${ }^{75}$ For the same reason, it is more susceptible of treatment within traditional contract doctrine. Moreover, because it does not purport to be based on any system of organizational authority, the governmental analogy is less appropriate; judicially imposed protection of democratic participation, for example, would not apply.

Yet, as we shall point out, the individual in this context finds himself in the same position of inferior bargaining as that which obtains with the powerful voluntary organization. In each case the service or product to the individual is of significant and sometimes overwhelming iniportance; in each case one may view the institution as leading the public to expect, and holding itself out to provide, goods or services of a particular nature or quality; in each case, too, the institution may be one which lias been traditionally or is currently regulated in other respects by statute.

These factors either singly or collectively may occasion the judicial

74 See generally Comment, Exhaustion of Remedies in Private, Voluntary Associations, 65 YALE L.J. 369 (1956). As to the requirement in labor unions, see J. GRodn, UNION Governatent aNd THE LAW 35-52 (1961).

75 Status concepts are typically associated with continuing relationships, in which the participants are involved more extensively than they are in a single contractual transaction. See P. Nonet, The Decline of Contract 41-59 (1964) (unpublished M.A. thesis in University Library, Umiversity of California, Berkeley). 
imposition of obligations based upon relationship or status; lere again, as in the case of voluntary associations, courts at times insist that the product or service conform to the reasonable expectations of the consuming public. We see in the business enterprise cases a sensitivity of the courts to the plight of the individual in this highly organized and complex society, a response which generates cases imposing obhgations that flow from the relationship of the parties.

In a variety of situations involving commercial enterprises the courts have held that, regardless of limitations sought to be imposed by contract, the product or service tendered to the public must conform to the reasonable expectations of the persons to be served. The cases illustrate judicial reluctance to enforce two types of contractual provisions: First, those reheving the enterprise from hability for negligence in performing obligations based on its relationship with the other party $;^{76}$ and second, those restricting the kind of obligation owed to the consuming public. ${ }^{77}$

The first category of cases, nullifying contractual provisions which would exonerate the vendor of goods or services from the consequences of his own negligence, originated with attempts by public carriers to limit their common law hability by private contract. ${ }^{78}$ With increasing frequency, judicial techniques developed in response to such efforts to limit hability have been applied in other areas. Instances of such application occur in cases involving several relationships, for example, commercial bailee and bailor, ${ }^{79}$ landlord and tenant, ${ }^{80}$ bank and deposi-

${ }^{76}$ See Tunkl v. Regents of Univ. of Cal., 60 Cal. 2d 92, 383 P.2d 441, 32 Cal. Rptr. 33 (1963) (hospital-patient); Papakalos v. Shaka, 91 N.H. 265, 18 A.2d 377 (1941) (landlordtenant); Miiller's Mut. Fire Ins. Ass'n v. Parker, 234 N.C. 20, 65 S.E.2d 341 (1951) (bailment).

77 See Steven v. Fidelity \& Cas. Co., 58 Cal. 2d 862, 377 P.2d 284, 27 Cal. Rptr. 172 (1962) (insurance); Henningsen v. Bloonfield Motors, Inc., 32 N.J. 358, 161 A.2d 69 (1960) (nuanufacturer's liability).

78 See Bisso v. Inland Waterways Corp., 349 U.S. 85, 89-90 (1955). The carrier cannot exempt itself fron liability for negligence. E.g., United States v. Atlantic Mut. Ins. Co., 343 U.S. 236, 239 (1952); Crane v. Railway Express Agency, 369 Ill. 110, 15 N.E.2d 866 (1938); P. Garvan Inc. v. New York Cent. \& H.R.R.R., 210 Mass. 275, 96 N.E. 717 (1911). The carrier can only limit its liability by contract if the shipper has the option of paying more and receiving full protection. E.g., Union Pac. R.R. v. Burke, 255 U.S. 317 (1921); Toyo Kisen Kabushiki Kaisha v. Willits \& Co., 17 F.2d 762 (9th Cir. 1927) ; Hubbard v. Matson Navigation Co., 34 Cal. App. 2d 475, 93 P.2d 846 (1939). See generally 6 S. WuIIsToN, Contracts $\$ 1751 \mathrm{C}$ (rev. ed. 1938).

${ }^{79}$ See Miller's Mut. Fire Ins. Ass'n v. Parker, 234 N.C. 20, 65 S.E.2d 341 (1951); Baione v. Heavey, 103 Pa. Super. 529, 158 A. 181 (1932). See generally Annot., 175 A.L.R. 8, 120-35 (1948).

80 Papakalos v. Shaka, 91 N.H. 265, 18 A.2d 377 (1941) (exculpatory clause void). See Arensberg, Limitation by Bailees and by Landlords of Liability for Negligent Acts, 51 Drck. L. Rev. 36, 37 (1946) ; Note, 15 U. PrTT. L. Rev. 493 (1954). Exculpatory clauses in leases have been held valid in most jurisdictions as not against public policy. E.g., Mills v. Ruppert, 167 Cal. App. 2d 58, 333 P.2d 818 (1959); Simmons v. Columbus Venetian Stevens 
tor, $^{81}$ hospital patient, ${ }^{82}$ utility and consumer, ${ }^{83}$ and others of a similar character. ${ }^{84}$ In Part A of this section we shall attempt to show how these concepts apply in typical cases.

The second category of cases, unlike the first, does not involve attempts to obtain anticipatory, relief from liability for negligent conduct. Rather it involves purveyors of goods or services who seek by private agreement to exact limitations upon hability for failure to perform contractual duties. In nullifying such attempts, the courts have manifested a growing tendency to require certain institutions, including insurers, ${ }^{85}$ banks, ${ }^{80}$ and vendors of products that may cause injury to human life, ${ }^{87}$ to render the performance which the average member of the public might reasonably expect of such enterprises. Part $\mathbf{B}$ includes a more detailed analysis of illustrative cases.

In both categories of cases, courts now impose public obligations upon private undertakings in order to protect the individual from the economically inore powerful enterprises. In denying relief to the more powerful party, a few courts have stressed the oppressive circumstances surrounding a particular agreement. ${ }^{88}$ Most courts, however, have placed greater

Bldgs., Inc., 20 III. App. 2d 1, 155 N.E.2d 372 (1958). They are strictly construed, however, and usually will not exempt the landlord for lability for "active" neghigence. E.g., Barkett v. Brucato, 122 Cal. App. 2d 264, 264 P.2d 978 (1953); Simmons v. Pagones, 66 S.D. 296, 282 N.W. 257 (1938). See generally Annot., 26 A.L.R.2d 1044, 1054-56 (1952); Annot., 175 A.L.R. 8, 83-94 (1948).

81 See Frankini v. Bank of America Nat'l Trust \& Savings Ass'n, 12 Cal. App. 2d 298, 55 P.2d 232 (1936) ; Speroff v. First-Central Trust Co., 149 Ohio St. 415, 79 N.E.2d 119 (1948); Thomas v. First Nat'l Bank, 376 Pa. 181, 101 A.2d 910 (1954). See generally Annot., 175 A.L.R. 8, 78-82 (1948).

82 See Tunkl v. Regents of Univ. of Cal., 60 Cal. 2d 92, 383 P.2d 441, 32 Cal. Rptr. 33 (1963); Note, 52 CaIf. L. REv. 350, 352 (1964); Note, 11 U.C.L.A.L. REv. 639, 642 (1964); Annot., 6 A.L.R.3d 704 (1966).

83 Fairfax Gas \& Supply Co. v. Hadary, 151 F.2d 939 (4th Cir. 1945); Denver Consol. Elec. Co. v. Lawrence, 31 Colo. 301, 73 P. 39 (1903); March v. Carbide \& Carbon Chem. Corp., 265 App. Div. 1064, 39 N.Y.S.2d 493 (1943) ; Bastian v. Keystone Gas Co., 27 App. Div. 584, 50 N.Y.S. 537 (1898); Emery v. Rochester Tel. Corp., 156 Misc. 562, 282 N.Y.S. 280 (Sup. Ct. 1935), rev'd on other ground, 271 N.Y. 306, 3 N.E.2d 434 (1936); Lone Star Gas Co. v. Veal, 378 S.W.2d 89 (Tex. Ct. Civ. App. 1964); Reeder v. Western Gas \& Power Co., 42 Wash. 2d 542, 256 P.2d 825 (1953). See generally Annot., 175 A.L.R. 8, 38-70 (1948).

84 See Tyler v. Dowell, Inc., 274 F.2d 890, 895 (10th Cir.), cert. denied, 363 U.S. 812 (1960) (drilling contract); Mohawk Drilling Co. v. McCullough Tool Co., 271 F.2d 627, 632-33 (10th Cir. 1959) (oil well servicing contract).

85 See National Farmers Umion Property \& Cas. Co. v. Colbrese, 368 F.2d 405, 411 (9th Cir. 1960); Messina v. Mutual Benefit Health \& Acc. Ass'n, 228 F. Supp. 865 (D.D.C. 1964); Lowell v. Maryland Cas. Co., 65 Cal. 2d 298, 419 P.2d 180, 54 Cal. Rptr. 116 (1966); Gray v. Zurich Ins. Co., 65 Cal. 2d 263, 419 P.2d 168, 54 Cal. Rptr. 104 (1966); Steven v. Fidelity \& Cas. Co., 58 Cal. 2d 862, 377 P.2d 284, 27 Cal. Rptr. 172 (1962). 86 See Los Angeles Inv. Co. v. Home Savings Bank, 180 Cal. 601, 182 P. 293 (1919). 87 See Henningsen v. Blooinfield Motors, Inc., 32 N.J. 358, 161 A.2d 69 (1960).

88 See Fairfax Gas \& Supply Co. v. Hadary, 151 F.2d 939 (4th Cir. 1945), in which the 
emphasis upon the institutional relationship of the parties and upon their respective roles in society; they have concluded that the status of the purveyor of goods or services itself imposes an obligation to fulfill certain public functions. Thus, if the institution or transaction exhibits one or more of the "public service" criteria suggested in this Article, courts may impose upon the performer the obligation to render such performance as fulfills the reasonable expectation of the other party. In reaching this result, courts sometimes expressly recognize these "public service" factors; more often they employ orthodox terminology. Courts may articulate the obligation, for example, in terms of a common law relationship like bailment. ${ }^{89}$ They may speak of the intent of the parties, imposing an obligation in the course of interpreting a contract..$^{90}$ Finally, they may describe the obligation in the vague language of "public policy"s1 or in the descriptive terms of more recently developed doctrines, such as enterprise liability..$^{22}$ In all these cases, allusions to the actual relationship of the parties, to circumstances surrounding the transaction, and to the changing role of the institution involved, indicate that courts are extending old doctrines and terminology to impose obligations based on relationships characteristic of a new, industrial society.

\section{A. Limitations on Liability for Negligence}

Courts refuse to enforce contract provisions exempting certain enterprises from liability for negligence. Professional bailees, landlords, banks

defendant gas company knew of a gas leak in the plaintiff's home and took no steps to repair it or to warn the plaintiff, and Hiroshima v. Bank of Italy, 78 Cal. App. 362, 377, 248 P. 947, 953 (1926), in which an exculpatory clause in a stop-payment notice was held void as to a plaintiff who could not read English. Judicial negation of private bargains through the developing doctrine of the unconscionable contract is analogous to the imposition of public obligations upon private undertakings. Writing for the U.S. Court of Appeals, District of Columbia Circuit, Judge Skelly Wright refused to enforce a printed form contract for the installment purchase of furniture which provided in a "rather obscure provision" that "the debt incurred at the time of purchase of each item was secured by the right to repossess all the items previously purchased by the same purchaser, and each new item purchased automatically became subject to a security interest arising out of the previous dealings." Williams v. Walker-Thomas Furniture Company, 350 F.2d 445, 447 (D.C. Cir. 1965). The court leld the contract "unconscionable" because it posed "an absence of meaningful choice on the part of one of the parties together with contract terms which are unreasonably favorable to the other party." Id. at 449. The analogy of this approach to that developed in this Article is demonstrated by the court's reliance upon the "gross inequahity of bargaining power," the possible lack of opportunity "to understand the terms of the contract" because of the "maze of fine print," $i d$., and the frequent references to Henmingsen v. Bloomfield Motors, Inc., 32 N.J. 358, 161 A.2d 69 (1960). Id. at 448 n.2, 449 n.7, 450 n.12. See also Collims, Contracts, 1965 Annual Survey of AxIarican Law 326-330.

89 Miller's Mut. Fire Ins. Ass'n v. Parker, 234 N.C. 20, 65 S.E.2d 341 (1951).

90 Barkett v. Brucato, 122 Cal. App. 2d 264, 264 P.2d 978 (1953).

91 Malone v. Santora, 135 Conn. 286, 64 A.2d 51 (1949).

92 Greenman v. Yuba Power Prods., Inc., 59 Cal. 2d 57, 377 P.2d 897, 27 Cal. Rptr. 697 (1963). 
and hospitals may thus be judicially required to meet certain standards of conduct whatever their contractual relations with the public.

\section{Bailor-Bailee Relationship}

When dealing with owners and operators of parking lots, parcel checkrooms, garages and warehouses, many courts invoke traditional rules of bailment to impose minimum obligations on the performance of sucls undertakings. Exculpatory clauses in contracts involving these enterprises are struck down as inconsistent with the legal relationship of bailor and bailee. ${ }^{93}$ Despite judicial reliance on mechanical rules of bailment and on language of "public policy,"94 sucli decisions rest on a recognition of the public service nature of these enterprises and on insistence that the service conform to that which the public may reasonably expect.

In Agricultural Insurance Company v. Constantine, ${ }^{95}$ for example, the court used bailment language to emphasize the obligations arising from a parking lot owner's relationship with his customers. Although the case apparently rested on the theory that contracts limiting "liability for negligence" in parking lot tickets are "generally regarded as against public policy," the court explained that the ticket was a mere "token for the identification of the bailed property." provisions could in no way alter customary bailment relationships without clear assent by the bailor, who otherwise expects the bailee to carry out his obligation of due care. Although the court spoke both of "public policy" and of the bailment contract, it emphasized the bailor's expectation of a certain quality of performance by the bailee..$^{98}$

Cases like Constantine express status obligations in traditional bailment language, but judicial use of "public policy" terminology serves to adapt the bailor-bailee relationship to modern circumstances. "The trend of modern authorities holds that sucl an effort on the part of a bailee

93 See, e.g., Malone v. Santora, 135 Conn. 286, 292, 64 A.2d 51, 53-54 (1949); Miller's Mut. Fire Ins. Ass'n v. Parker, 234 N.C. 20, 23-24, 65 S.E.2d 341, 343-44 (1951); Agricultural Ins. Co. v. Constantine, 144 Ohio St. 275, 282, 58 N.E.2d 658, 662 (1944); Wendt v. Sley System Garages, Inc., 124 Pa. Super. 224, 188 A. 624 (1936). See generally Annot., 175 A.L.R. 8, 110-44 (1948).

94 See, e.g., Michigan Millers Mut. Fire Ins. Co. v. Canadian Northern Ry., 58 F. Supp. 326, 329 (1944), afj'd, 152 F.2d 292 (1945); Malone v. Santora, 135 Conn. 286, 293, 64 A.2d 51, 54 (1949); Agricultural Ins. Co. v. Constantine, 144 Ohio St. 275, 283, 58 N.E.2d 658, 663 (1944); England v. Lyon Fireproof Storage Co., 94 Cal. App. 562, 571, 271 P. 532, 536 (1928). In Malone v. Santora, supra, the court found an exculpatory provision in a parking lot ticket "revolting to the moral sense, and contrary alike to the salutary principles of law and a sound public policy," but did not particularize upon these observations. Id. at 293, 64 A.2d at 54, quoting Welch v. Boston \& A.R.R., 41 Conn. 333, 342 (1874).

85144 Ohio St. 275,58 N.E.2d 658 (1944).

96 Id. at 283,58 N.E.2d at 663 .

87 Id. at 280,58 N.E.2d at 661 .

88 See id. at $281-82,58$ N.E.2d at 662. 
to exempt himself from negligence is contrary to public policy. ${ }^{200}$ Thus, an old common law relationship receives new content and purpose in response to modern circumstances surrounding the bailment transaction.

In Miller's Mutual Fire Insurance Association v. Parker, ${ }^{100}$ another parking lot case, the court openly recognized the impact of today's integrated society on the bailment relationslip. Acknowledging the bailee's right expressly to limit his own liability when the parties possess equal bargaining power and when the contract is consistent with public policy, the court discussed the actual role of the modern parking lot. "The complexity of today's commercial relations and the constantly increasing number of automobiles render the question of parking a matter of public concern ...."101 Parking lot operators are "professional bailees" who "hold themselves out to the public as being possessed of convenient means and special facilities to furnish the service offered for a price. They deal with the public on a uniform basis and at the same time impose or seek to impose predetermined conditions which rob the customer of any equality of bargaining power."102 Such characteristics are equally applicable to "garages, parcel check rooms, and warehouses."103 In such circumstances, the bailee may not contract against his own negligence.

Although the Miller's Mutual court used bailment language, it emphasized the "duties of public service" of a "public service corporation. ${ }^{.1104}$ It rehed not only on traditional obligations of the bailor-bailee relationship, but on such obligations examined in the hight of the expectations and relative bargaining power of the parties.

\section{Landlord-Tenant Relationship}

Courts may derive similar obligations from the landlord-tenant relationship. Whatever the economic situation as to land may have been in the less congested cities of the nineteenth century, twentieth century developments in urban areas in large measure have vested superior bargaining power in the landlord. ${ }^{105}$ As one Mlinois court has observed, for example, "[I]n large cities, due to such orgamizations as real estate

99 England v. Lyon Fireproof Storage Co., 94 Cal. App. 562, 571, 271 P. 532, 536 (1928). 100234 N.C. 20,65 S.E.2d 341 (1951).

101 Id. at 24,65 S.E.2d at 344.

102 Id.

103 Id. at 23,65 S.E.2d at 344.

104 Id. at $22,65 \mathrm{SE} .2 \mathrm{~d}$ at 342 .

105 When houses are scarce and landlords are grasping, Blackstone's proposition that the public good is in nothing more essentially interested than in the protection of every individual's private rights is not the popular view. A crowded, urban, industrial community looks to society for protection against predatory individuals, natural or artificial, and resents doctrines that protect these individuals against society for fear society will oppress them.

R. Pound, THe SPIRIT OF THE Comaron Law 102-03 (1921). The change in bargaining power of landlord and tenant has resulted in the enactment of statutes making void exculpatory 
boards, managers' associations and large renting agencies, there has developed the use of a lease which is very generally uniform in its terms." 1100 As in the bailment cases, courts have recognized such changed circumstances even while doing so through traditional legal terminology.

In refusing to enforce exculpatory lease provisions exonerating landlords from negligence, courts often speak of the intent of the parties. ${ }^{107}$ As in bailment cases, however, such general language may represent the court's imposition of obligations based on the public service nature of the landlord-tenant relationship.

In Barkett v. Brucato, ${ }^{108}$ for example, the court held that a general waiver clause in a lease should not be interpreted to cover affirmative negligence by the landlord, since the parties "could not have intended to provide that the landlord should not be liable for acts amounting to active and affirmative negligence." 109 The court noted a "marked tendency in recent cases" so to interpret exculpatory clauses; ${ }^{110}$ the courts thus, through traditional language of contract imterpretation, express a response to changes in the actual landlord-tenant relationship.

In Simmons v. Columbus Venetian Stevens Buildings, Incorporated, ${ }^{111}$ the court discussed at length the factual circumstances surrounding the landlord-tenant relationship, empliasizing the landlord's superior bargaining power and widespread use of standard leases. ${ }^{112}$ It indicated that although execution of one exculpatory clause may not be "a matter of public concern, ... the execution of numerous exculpatory clauses ... made the leases a matter of social relationship."113 The court explained that the reasons for excluding exculpatory clauses in the "semi-public relationship" between common carriers and passengers and shippers also apply to the landlord-tenant relationship, because both are matters of public interest. ${ }^{114}$

The importance of the service, the unequal bargaining power of the

clauses in leases. Mass. Gen. Laws AnN. ch. 186, § 15 (1958) ; N.Y. ReAL Prop. LAw § 234 (McKinney 1945), now N.Y. GeN. ObLTGations Law \$ 5-321 (McKinney N.Y. Real Prop. Supp. 1967). See Rehberg, Exculpatory Clauses in Leases, 15 GA. B.J. 389, 396-400 (1953). ${ }_{106}$ Simmons v. Columbus Venetian Stevens Bldgs., Inc., 20 Ill. App. 2d 1, 25-26, 155 N.E.2d 372, 384 (1958).

$107 \mathrm{See}$ the interesting discussion of Presiding Justice Peters, Barkett v. Brucato, 122 Cal. App. 2d 264, 278, 264 P.2d 978, 988 (1953); Drescher Rothberg Co. v. Landeker, 140 N.Y.S. 1025 (Sup. Ct. App. T. 1913).

108122 Cal. App. 2d 264, 264 P.2d 978 (1953).

109 Id. at 278,264 P.2d at 988.

$110 I d$.

11120 III. App. 2d 1, 155 N.E.2d 372 (1958). Although the case upheld the validity of an exculpatory clause on the basis of precedent, the whole opimion is an argument for refusing to enforce such elauses. See id. at 30-32, 155 N.E.2d at 386-87.

112 Id. at 25-26, $155 \mathrm{~N} . \mathrm{E} .2 \mathrm{~d}$ at 384 .

113 Id. at $30-31,155$ N.E.2d at 386 .

$114 I d$. at $26-27,155$ N.E.2d at $384-85$. 
parties, and the fact that housing is subject to regulation by the state all indicate that the landlord-tenant relationship is one "affected with a public interest."115 Legislation in some states outlawing exculpatory clauses in leases indicates a general recognition of the public's interest in the relationship. ${ }^{116}$

\section{Banks and Hospitals}

Some cases present neither an historical coinmon law relationship, like a bailment, nor an encompassing contractual relationship, like a lease, as a basis for imposing liability. In such situations courts must rely more overtly on the expectations arising from the actual relationship between the parties. When banks and hospitals attempt to limit their own liability for negligence, courts, relying upon the modern roles of such institutions, sometimes impose obligations based on the public's reasonable expectations of the services to be rendered. ${ }^{117}$

Although some decisions hold otherwise, ${ }^{118}$ a great number of courts follow the rule that banks cannot exculpate themselves from negligence for paying a stopped clieck by so providing in a stop-payment notice. ${ }^{110}$ Banks bear a duty to exercise due care in making payment from the account; courts will hold them liable for failure to comply with it. ${ }^{120}$ One

115 "Inns are public callings and were so considered even at early common law. There is some support for the view that even the renting of house is a business affected with a public interest. At least, courts have held that in times of emergency, the business of renting houses is sufficiently affected with a public interest to justify regulations concerning rents." F. HaIl, The Concept of a Business AfFected with a Public Interest 50 (1940).

116 See authorities cited note 105 supra.

117 See Tunkl v. Regents of Umiv. of Cal, 60 Cal. 2d 92, 98-101, 383 P.2d 441, 444-47, 32 Cal. Rptr. 33, 36-39 (1963); Hiroshima v. Bank of Italy, 78 Cal. App. 362, 377, 248 P. 947,953 (1926).

118 Hodnick v. Fidelity Trust Co., 96 Ind. App. 342, 183 N.E. 488 (1932); Tremont Trust Co. v. Burack, 235 Mass. 398, 126 N.E. 782; Gaita v. Windsor Bank, 251 N.Y. 152, 167 N.E. 203 (1929). See Annot., 1 A.L.R.2d 1155, 1156 (1948). See also Irish \& Swartz Stores v. First Nat'l Bank, 220 Ore. 362, 349 P.2d 814 (1960).

119 Grisinger v. Golden State Bank, 92 Cal. App. 443, 268 P. 425 (1928); Hiroshima v. Bank of Italy, 78 Cal. App. 362, 248 P. 947 (1926); Speroff v. First-Central Trust Co., 149 Ohio St. 415, 79 N.E.2d 119 (1948); Thomas v. First Nat'l Bank, 376 Pa. 181, 101 A.2d 910 (1954). Such agreements may be held unenforceable for failure of consideration. Commercial Bank v. Hall, 266 Ala. 57, 94 So. 2d 198 (1957); Calamita v. Tradesmen's Nat'l Bank, 135 Conn. 326, 64 A.2d 46 (1949); Reinhardt v. Passaic-Chifton Nat'l Bank \& Trust Co., 16 N.J. Super. 430, 84 A.2d 741 (App. Div. 1951), aff'd 9 N.J. 607, 89 A.2d 242 (1952). Using analogous reasoning, courts have held that banks cannot exculpate themselves from negligence by a provision in a passbook stating that its possession is sufficient evidence of ownership to make payment to any person producing it. E.g., Chase v. Waterbury Sav. Bank, 77 Conn. 295, 59 A. 37 (1904); Ladd v. Augusta Sav. Bank, 96 Me. 510, 52 A. 1012 (1902); Bulakowski v. Philadelphia Sav. Fund Soc'y, 270 Pa. 538, 113 A. 553 (1921).

120 E.g., Hiroshima v. Bank of Italy, 78 Cal. App. 362, 248 P. 947 (1926); Chase v. Waterbury Sav. Bank, 77 Conn. 295, 59 A. 37 (1904); Ladd v. Augusta Sav. Bank, 96 Me. 510, 52 A. 1012 (1902). 
may view this duty as arising from a bank's relationship with its customers. As one court observed:

[T] he banking public, as well as the particular individual who may be concerned in the giving of any stop notice, is interested in seeing that the bank is held accountable for the ordinary and regular performance of its duties . . . It may also be added that the testimony shows the parties in this case were not contracting upon an equal basis. ${ }^{121}$

Finally, courts may treat hospitals as public service mstitutions which cannot avoid liability for negligence througli exculpatory clauses. In Tunkl v. Regents of the University of California, ${ }^{122}$ the Califorma supreme court held invalid the provision in a lospital's agreement conditioning the patient's admission on his release of the hospital from any liability for future neghigence. Althougl the court held that the agreement violated a statutory provision forbidding exemption from negligence, ${ }^{123}$ the opinion rested on a ground broader than statutory interpretation. Holding the contract to be "affected with a public interest,"124 the court set out the characteristics of such an agreement:

It concerns a business of a type generally thought suitable for public regulation. The party seeking exculpation is engaged in performing a service of great importance to the public, which is often a matter of practical necessity for some members of the public. The party holds himself out as willing to perform this service for any member of the public who seeks it, or at least for any member coming within certain established standards. As a result of the essential nature of the service, in the economic setting of the transaction, the party invoking exculpation possesses a decisive advantage of bargaining strength against any member of the public who seeks his services. In exercising a superior bargaining power the party confrouts the public with a standardized adhesion contract of exculpation, and makes no provision whereby a purchaser may pay additional reasonable fees and obtain protection against negligence. Finally, as a result of the transaction, the person or property of the purchaser is placed under the control of the seller, subject to the risk of carelessness by the seller or his agents.125

Although courts rely on these characteristics in defining an enterprise as a public service institution, Tunkl is unique in containing all such factors. As the opinion indicated, however, a transaction whicls exhibits "some or all" of the characteristics is affected with a public interest. ${ }^{126}$ The cases in this Article which treat enterprises or transactions as affected with a public interest involve at least one of the factors enumerated in Tunkl.

121 Hiroshima v. Bank of Italy, 78 Cal. App. 362, 377, 248 P. 947, 953 (1926).

12260 Cal. 2d 92, 383 P.2d 441, 32 Cal. Rptr. 33 (1963).

123 CAL. Crv. Code $\$ 1668$ (West 1954).

12460 Cal. 2d at 98, 383 P.2d at 444, 32 Cal. Rptr. at 36.

125 Id. at 98-101, $383 \mathrm{P} .2 \mathrm{~d}$ at 445-46, 32 Cal. Rptr. at 37-38.

126 Id. at 98, 383 P.2d at 445, 32 Cal. Rptr. at 37 (emphasis added). 
In Darling v. Charleston Community Memorial Hospital, ${ }^{127}$ the Illinois supreme court held that a hospital could not himit its liability for alleged negligence to the amount of its liability insurance. Such a himitation, based on an assertion of charitable immunity, would permit hospitals "to determine whether or not they will be liable for their torts and the amount of that liability, if any." hospital is inconsistent with its modern relationship with the public:

The conception that a hospital does not undertake to treat the patient, does not undertake to act through its doctors and nurses, but undertakes instead simply to procure them to act upon their own responsibihty, no longer reflects the fact. Present-day hospitals, as their manner of operation plainly demonstrates, do far more than furnish facilities for treatment. .. . Certainly, the person who avails himself of 'hospital facilities' expects that the hospital will attempt to cure him, not that its nurses or other employees will act on their own responsibility.120

Each hospital must assume its expected obligation toward its patients and cannot predetermine for itself the extent of its responsibility by anticipatory exculpatory provisions.

\section{B. Limitations on Risks Undertaken}

As we have explaimed, when a party to a transaction "affected with a public interest" attempts contractually to deny or limit his own liability for negligence, in defiance of the reasonable expectations of the weaker party to the contract, courts may impose obhgations by refusing to enforce such clauses. ${ }^{130}$ Although they may invoke the language of common law relationships such as bailment, of contract interpretation, or of "public policy," the obligation they impose is based in each case on the relationship between the parties rather than on contract.

In a second group of cases, the purveyor of goods or services may try to limit by contract not his liability for negligence, but the kind of obligation he owes the public. The insurer, the bank, or the manufacturer may attempt to shift some of his business risks to the consumer. Again, many courts refuse to enforce such contract provisions and instead define the scope of the obligation in terms of the parties' reasonable expectations, ${ }^{131}$ thus adopting the approach suggested by Professor Kessler and

12733 III. 2d 326, 211 N.E.2d 253 (1965).

128 Id, at 337,211 N.E.2d at 260.

128 Id. at 332, 211 N.E.2d at 257, quoting Bing v. Thunig, 2 N.Y.2d 656, 666, 143 N.E.2d 3, 8 (1957) (emphasis added). See also Boll v. Sharp \& Dohme, Inc., 200 Misc. 1104, 107 N.Y.S.2d 174 (Sup. Ct. 1951), appeal dismissed, 306 N.Y. 669, 116 N.E.2d 498 (1953), aff'd, 307 N.X. 646, 120 N.E.2d 836 (1954).

130 See text accompanying notes 93-129 supra.

131 See Gray v. Zurich Ins. Co., 65 Cal. 2d 263, 419 P.2d 168, 54 Cal. Rptr. 104 (1966) (insurer); Los Angeles Inv. Co. v. Home Sav. Bank, 180 Cal. 601, 182 P. 293 (1919) (bank); Henningsen v. Bloomfield Motors, Inc., 32 N.J. 358, 161 A.2d 69 (1960) (manufacturer). 
other commentators for adhesion contracts. ${ }^{132}$

\section{Insurance Companies}

The concept that a contract is to be interpreted in the light of the parties' reasonable expectations lies deep in contract law. ${ }^{133}$ Basically courts have long looked to the language of the contract to find the meaning which the parties reasonably expected from the use of the words. Applying the concept somewhat differently, courts may derive the reasonable expectations of the parties from their relationship or status rather than from the consensual transaction itself. When the public service enterprise is an insurance company dealing with an insurance purchaser who is obviously the weaker party to the transaction, many courts in determining contractual obligations have examined the reasonable expectation of the average insured. ${ }^{134}$ Thus, courts have stricken from insurance contracts unclear, unexpected, inconspicuous, or unconscionable hmitations of liability which would frustrate the reasonable expectations of the insured. ${ }^{135}$ Courts have also refused to enforce clauses which would negate the principal protection which the insured would reasonably expect. ${ }^{136}$

In Steven v. Fidelity \& Casualty Company of New York, ${ }^{13 t}$ the in-

132 "In dealing with standardized contracts courts have to determine what the weaker contracting party could legitimately expect by way of services according to the enterpriser's 'calling' and to what extent the stronger party disappointed reasonable expectations based on the typical life situation." Kessler, Contracts of Adhesion-Some Thoughts about Freedom of Contract, 43 Corum. L. REv. 629, 637 (1943). See also Isaacs, The Standardizing of Contracts, 27 YaLE L.J 34, 38 (1917); Llewellyn, Book Review, 52 HaRv. L. Rev. 700, 704 (1939). For further discussions of the adhesion contract, see authorities cited in Note, Insurance: The Meaning of the Contract in Light of the Insured's Reasonable Expectations, 2 LINCoLN L. REv. 158 n.7 (1967).

133 See Patterson, The Interpretation and Construction of Contracts, 64 Corom. L. Rev. 833, 858 (1964); Comment, Contracts of Adhesion under California Lave, 1 U. SAN Francisco L. Rev. 306 (1967).

134 Patterson, supra note 133, at 858; see Kessler, supra note 132, at 637; Patterson, supra note 133, at 858. Significantly, in 1921 Dean Pound said:

[I]n the purely judicial development of our law we have taken the law of insurance practically out of the category of contract, and we have established that the duties of puhlic service companies are not contractual, as the nineteenth-century sought to make them, but are instead relational; they do not flow from agreements which the public servant may make as he chooses, they flow from the calling in which he has engaged and his consequent relation to the public.

R. Pound, The Spirm of the Contron LAW 29 (1921).

135 See, e.g., Messina v. Mutual Benefit Health \& Accident Ass'n, 228 F. Supp. 865, 868 (1964) ; Lowell v. Maryland Cas. Co., 65 Cal. 2d 298, 419 P.2d 180, 54 Cal. Rptr. 116 (1966); Lachs v. Fidelity \& Cas. Co., 306 N.Y. 357, 118 N.E.2d 555 (1954).

136 E.g., Glickman v. New York Life Ins. Co., 16 Cal. 2d 626, 635, 107 P.2d 252, 256

(1940). See also Kessler, supra note 132, at 635, 637.

13758 Cal. 2d 862, 377 P.2d 284, 27 Cal. Rptr. 172 (1962). 
sured purchased from an airport vending machine an insurance policy covering a contemplated airplane trip. A scheduled airliner was cancelled for one leg of the trip, and the nonscheduled aircraft which was substituted for it crashed, killing the insured. The Cahfornia supreme court held that a clause in the insurance policy excluding coverage for travel on nonscheduled airlines was too ambiguous to be enforced. Ostensibly interpreting an ambiguous clause, the court took into account both the unequal bargaining power of the parties and the reasonable expectation of the public: Through use of a vending machine, "[T]he insurer had adopted a means of selling policies whicli makes bargaining totally impossible,"138 and if the insurer "deals with the public upon a mass basis, the notice of noncoverage of the policy, in a situation in which the public may reasonably expect coverage, must be conspicuous, plain and clear."180

In Wernecke v. Pacific Fidelity Life Insurance Company ${ }^{140}$ insurance coverage was similarly defined on the basis of "what the ordinary layman might reasonably expect under the circumstances."141 The insured applied for insurance, paid an amount equal to the first premium, and received a receipt. The application and receipt came to the insurance company's home office, which determined, subsequent to the insured's intervening death in an automobile accident, that under company rules the insured was not insurable. The court stated:

To the ordinary layman, payment of an insurance premium constitutes payment for insurance protection, and when paid under circumstances such as in the instant case presupposes immediate commencement of protection although subject to termination by the insurance company in the event it is not satisfied with his insurability. ${ }^{142}$

Where the provisions of the receipt were contradictory, the layman's expectations should be fulfilled.

Steven and Wernecke rest in part upon judicial scrutiny of the language of the policy and the finding that the himitations of coverage were ambiguous or "esoteric." In this respect these courts did not depart from the many cases that undertake a painstaking analysis of policy provisions and, upon finding some ambiguity in them, read the clauses, in the timehonored manner, agamst the insurance company. ${ }^{143}$ But Steven and

138 Id. at 883,377 P.2d at 297,27 Cal. Rptr. at 185.

139 Id. at 878,377 P.2d at 294, 27 Cal. Rptr. at 182. See also Raulet v. Northwestern Nat'l Ins. Co., 157 Cal. 213, 107 P. 292 (1910).

140238 Cal. App. 2d 884, 48 Cal. Rptr. 251 (1965).

141 Id. at $887,48 \mathrm{Cal}$. Rptr. at 253.

142 Id.

143 See, e.g., Raulet v. Northwestern Nat'l Ins. Co., 157 Cal. 213, 224, 107 P. 292, 296 (1910). See Meyer, Contracts of Adhesion and the Doctrine of Fundamental Breach, $50 \mathrm{VA}$. L. REv. 1178, 1180 (1964). 
Wernecke relied, too, upon the proposition that the insurer could not win noncoverage by means of an inexplicit clause in the face of a reasonably expected coverage.

The reasonable expectation doctrine in insurance cases lias advanced beyond excluding ambiguous himiting provisions. Some decisions have rehied heavily upon the proposition that the insurer cannot enforce a provision which seeks to nullify the very essence of the insurance contract - the reasonably-to-be-expected protection. This proposition was suggested in an action by an insured against an insurer for failure to defend an action filed against hin for alleged assault. In Gray v. Zurich Insurance Company, ${ }^{144}$ the insurer contended that an exclusionary clause of the policy excused the defense of an action in which the plaintiff alleged that the insured intentionally caused the bodily injury. But the court pointed out that the designation of the pohicy as a "comprehensive personal liability" contract in itself connoted general protection for alleged bodily injury caused by the insured. ${ }^{145}$ The insurer had promised both to pay all sums that the insured became legally obligated to pay for bodily injury and to defend any suit against the insured alleging sucl injury, even if the allegations of the complaint were false or fraudulent. Such promises, without further clarification, would lead the insured reasonably to expect the insurer to defend him against suits seeking damages for bodily injury, whether the alleged cause was intentional or inadvertent.

The California supreme court said:

In summary, the individual consumer in the highly organized and integrated society of today must necessarily rely upon institutions devoted to the public service to perform the basic functions which they undertake. At the same time the consumer does not occupy a sufficiently strong economic position to bargain with such institutions as to specific clauses of their contracts of performance, and, in any event, piecemeal negotiation would sacrifice the advantage of uniformity. Hence the courts in the field of insurance contracts have tended to require that the insurer render the basic insurance protection which it has held out to the insured. This obhgation becomes especially manifest in the case in which the insurer has attempted to limit the principal coverage by an unclear exclusionary clause. We test the alleged limitation im the light of the insured's reasonable expectation of coverage; that test compels the indicated outconie of the present hitigation..$^{146}$

In Lagomarsino v. San Jose Abstract and Title Insurance Company, ${ }^{147}$

14465 Cal. 2d 263, 419 P.2d 168, 54 Cal. Rptr. 104 (1966), noted in 55 Calif. L. Rev. 1104 (1967) and 2 LINCOLN L. REv. 157 (1967) and 14 U.C.L.A. L. Rev. 1328 (1967).

145 Id. at 272,419 P.2d at 173, 54 Cal. Rptr. at 109.

146 Id. at 280, 419 P.2d at 179, 54 Cal. Rptr. at 115.

147178 Cal. App. 2d 455, 3 Cal. Rptr. 80 (1960). 
a California court of appeal interpreted a title insurance policy's coverage in terms of the relationship between insurer and insured and in liglut of the latter's reasonable expectation of protection. The policy ambiguously described the triangular piece of insured property by reference both to a railroad right of way and to iron pipes set in the ground. The insurer sought to avoid the risk by asserting that the right of way prevailed over courses and distances and therefore that title was guaranteed only to the smaller area of land. The court refused to allow the insurer to "place a selective construction upon the description, or an ambiguity in it, which will defeat its own obligation."148 The court defined the title company's obligation to "give the insured the protection which he reasonably had a right to expect" as arising from "the function it performs and the relationship to the insured which it assumes."140

\section{Banks}

Courts have held that banks, as public service institutions, cannot enforce contractual provisions that would himit liability in a manner not expected by, and not clearly communicated to, the depositor. ${ }^{150}$

In Los Angeles Investment Company v. Home Savings Bank, ${ }^{151}$ for example, an "Agreement with Depositor," printed in the passbook, included a provision that after ten days the depositor could not question the genuineness of indorsements. The plaintiff depositor sued to recover the amount of checks drawn by the plaintiff upon the deposit account and paid by the defendant bank on forged indorsements. Holding that the "average man" would not trouble to read such a provision and that it materially changed the "usual obligation" of the bank, the court refused to enforce it without evidence of the depositor's consent. The court said:

This statement is not signed by the plaintiff, nor is there any showing that it was called to the plaintiff's attention or wittingly agreed to by it. It is just the character of thing that the average man would not

148 Id. at 463-64, 3 Cal. Rptr. at 85.

149 Id. at 464, 3 Cal. Rptr. at 85, quoting Coast Mut. Bldg. Loan Ass'n v. Security Title Ins. \& Guar. Co., 14 Cal. App. 2d 225, 229, 57 P.2d 1392, 1393 (1936). To the same effect see the opinion of Mr. Justice Fleming in Murray v. Title Ins. \& Trust Co., 250 A.C.A. 313, 316, 58 Cal. Rptr. 273, 276 (1967), stating as follows:

In defense, the title company initially relies on certain exclusions purporting to restrict its coverage to the specific lot described in the policy and to disclaim responsibility for defects in the title to adjoining streets, and the like. We are not impressed with this defense, and we have no hesitancy in finding the title company's blanket exclusions from the coverage of its policy wholly inconsistent with the protection which the face of the policy purports to offer. (Steven v. Fidelity \& Casualty Co. of New York, 58 Cal. 2d 862, 879-83 [27 Cal. Rptr 172, 377 P.2d 284].) 150 See Wells v. Black, 117 Cal. 157, 48 P. 1090 (1897); Ackenhausen v. People's Sav. Bank, 110 Mich. 175, 68 N.W. 118 (1896). See generally Annot., 60 A.L.R.2d 708 (1958). 151180 Cal. 601, 182 P. 293 (1919). 
trouble to read, or reading would fail to appreciate the significance of the inclusion in it of "indorsements," and the fact that it very materially changed the usual obligation of a bank to its depositors. There is no reason, so far as we know, why a depositor may not make such an agreenent if he deliberately chooses to do so, unreasonable as it is. But it is evident that the statement comes in the category of "traps for the unwary," and before such statement can be given effect as a contract binding upon the depositor and changing in a substantial particular the relation which presumably he thought he was entering into, it inust appear affirmatively that he consented and agreed to it. ... 152

Frankini v. Bank of America National Trust \& Savings Association is another such case. ${ }^{153}$ There the defendant bank contended that the plaintiff depositor had waived his right to recover because of failure to object to the bank statements or to claim his alleged credit within the ten-day period required by a provision in an agreement entitled "Authorization to Mail Statements and Vouchers." Although the plaintiff had signed the authorization, the court held it did not frustrate his recovery because it had not been called to his attention; "the instrument was presented to him as a mere written request for monthly statements ... [and] was retained by the bank."154

It should be noted that, in cases involving insurance companies and banks, courts have used the reasonable expectation doctrine in two ways: They have rejected unclear, unexpected, imconspicuous, and unconscionable provisions that would himit the imstitution's hability; ${ }^{\mathbf{1 5 5}}$ and they have refused to enforce clauses which negate the principal or essential protection which the individual who deals with the institution would reasonably expect. ${ }^{150}$ Perhaps the second application is the more important. It reaches to the heart of the concept of the public service institution in its insistence that the institution, as a public functionary, perform the basic undertaking that it holds itself out as doing. ${ }^{157}$ The

152 Id. at 613,182 P. at 298.

15312 Cal. App. 2d 298, 55 P.2d 232 (1936).

154 Id. at 303,55 P.2d at 234.

155 See text accompanying notes 137-43 supra.

156 See text accompanying notes 144-54 supra.

157 The concept that the insurer undertakes a fundamental duty to the insured which the courts generally should effectuate finds expression in Glickman v. New York Life Ins. Co., 16 Cal. 2d 626, 634-35, 107 P.2d 252, 256 (1940):

Contracts of insurance slould be viewed in the light of their general objects and purposes, including the legitimate conditions prescribed by the insurer (Raulet $v$. Northwestern etc. Ins. Co., 157 Cal. 213 [107 P. 292]). In general, the object and purpose of insurance is to indemnify the insured in case of loss, and ordinarily such indemnity should be effectuated rather than defeated. . . Policies of insurance create reciprocal rights and obligations .... An insured is entitled to the protection which he buys and for which he pays substantial premiums. 
depositor expects the bank to perform its "usual obligations"; courts will not enforce the bank's attempt to avoid such responsibility. The insurer is supposed to insure; the public expects it to do so, and many courts insist that it do so, despite the nicety of sophisticated phrases of limitation or exclusion. The present quest for the uncertain clause, pursued by many courts, may end in the formulation of the doctrine that the insurer cannot by the most certain and understandable language negate the essence of his bargain.

As Professor Meyer has suggested, ${ }^{158}$ the recent English doctrine of "fundamental breach" represents an analogous approach. The rule is designed to invalidate attempted disclaimers by which the promisor would invalidate that obligation which the courts consider the essence of the transaction. ${ }^{159}$ The Enghish approach would replace judicial attempts to find ambiguous or unconscionable terms with a straightforward annulment of clauses inconsistent with the basic obligations of the contract. "Perhaps 'fundamental obligation' would better express the doctrine's notion of an irreducible core duty, a duty which arises from the relationship created by the contract rather than from the specific terms."100 It may be noted that the "core duty" coincides with that performance by the public service enterprise which the public would reasonably expect.

\section{Manufacturers and Distributors}

Courts have come to regard the relationship between a purveyor of goods and a consumer as an appropriate one for the imposition of duties not arising from contract. ${ }^{101}$ The manufacturer or distributor normally

158 Meyer, supra note 143 , at 1188 .

159 One English court stated: "[E]xempting clauses are nowadays all held to be subject to the overriding proviso that they only avail to exempt a party when he is carrying out his contract, not when he is deviating from it or is guilty of a breach which goes to the root of it." J. Spurling Ltd. v. Bradshaw, [1956] 1 W.L.R. 461, 465 (C.A.) (emphasis added). In a 1966 case, however, the House of Lords abandoned the doctrine of fundamental breach as a rule of law. Suisse Atlantique Société d'Armement Maritime S.A. v. N.V. Rotterdamsche Kolen Centrale, [1966] 2 W.L.R. 944. Although they did so in dictum, the "members of the House were, nevertheless, unanimous that there was no substantive doctrine of fundamental breach and that the question whether an exception clause was apphicable where there had been a fundamental breach was one of the true construction of the contract." Coote, The Rise and Fall of Fundamental Breach, 40 AvsTu. L.J. 336, 343 (1967). See Tiley, Fundamental Breach, 110 Sox. J. 730 (1966).

160 Meyer, supra note 143 , at 1188 .

101 See generally Cowan, Some Policy Bases of Products Liability, 17 Stan. L. Rev. 1077, 1086-87 (1965); Posel, Sales and Sales Financing, 16 Rotgers L. Rev. 329, 331 (1962); Rapson, Products Liability Under Parallel Doctrines: Contracts Between the Uniform Commercial Code and Strict Liability in Tort, 19 Rutcers L. Rev. 692, 293-94 (1965); Note, Disclaimer Clauses in Standardized Warranties: Henningsen v. Bloomfield Motors, Inc., 46 Corkerc L.Q. 608 (1961); Comment, Disclaimers of Warranty in Consumer Sales, 77 Harv. L. REv. 318, 322-23, 325 (1963). 
exerts greater bargaining power than does the consumer, and he undertakes a service of importance to the public in whicl the public must rely on the seller for the quality of the product. Courts refuse to enforce the vendor's disclaimer, and tend to protect the individual, the weak bargainer, against the economically more powerful vendor. ${ }^{162}$

The terminology used by courts to impose obligations on a vendor may be that of implied warranty ${ }^{163}$ or of strict liability in tort. ${ }^{164}$ The important element for the courts, however, is recognition of the impact of modern commercial conditions on the relationship of buyer and seller. As one court put it, "It must be said that in the present-day marketing milieu, treatment of the manufacturer's liability to ultimate purcliasers or consumers in terms of implied warranty is simply using a convenient legal device or formalism to accomplish the purpose."165

Most of the elements of a public service enterprise were recognized by the court in Henningsen v. Bloomfield Motors, Incorporated ${ }_{2}^{106}$ which held void as a matter of law Chrysler's attempted disclaimer of an implied warranty of merchantability. The court pointed out that to many people an automobile is a necessity, ${ }^{167}$ that automobile manufacturers through massive advertising hold themselves out as providing products of a certain quality, ${ }^{168}$ that the consumer is in an inferior bargaining position, and that he is often faced with a standardized contract. ${ }^{169}$ The court further noted that legislation regulating various aspects of the manufacture and use of automobiles indicates the public importance of the industry. ${ }^{170}$ The court expressly analogized the automobile industry to such "semi-public services" as common carriers, checkrooms, and parking lots. ${ }^{171}$ Given these circumstances, "[W]hen a manufacturer puts a new automobile in the stream of trade and promotes its purchase by the public, an implied warranty that it is reasonably suitable for use as sucl accompanies it into the hands of the ultimate purchaser..$^{172}$

In the leading case of Greenman v. Yuba Power Products, Incorpo-

162 See, e.g., Greenman v. Yuba Power Prods., Inc., 59 Cal. 2d 57, 377 P.2d 897, 27 Cal. Rptr. 697 (1963); Henningsen v. Bloomfield Motors, Inc., 32 N.J. 358, 161 A.2d 69 (1960).

163 Henningsen v. Blooinfield Motors, Inc., 32 N.J. 358, 161 A.2d 69 (1960).

164 Greenman v. Yuba Power Prods., Inc., 59 Cal. 2d 57, 377 P.2d 897, 27 Cal. Rptr. 697 (1963).

165 Santor v. A \& M Karagheusian, Inc., 44 N.J. 52, 64, 207 A.2d 305, 311 (1965).

16632 N.J. 358,161 A.2d 69 (1960).

167 Id. at $386,161 \mathrm{~A} .2 \mathrm{~d}$ at 85 .

168 Id. at $385,161 \mathrm{~A} .2 \mathrm{~d}$ at 84 .

160 Id. at 390,161 A.2d at 87 .

170 Id. at $387,161 \mathrm{~A} 2 \mathrm{~d}$ at 85 .

171 Id. at 396-99, $161 \mathrm{~A} .2 \mathrm{~d}$ at 91-92.

172 Id. at $384,161 \mathrm{~A} .2 \mathrm{~d}$ at 84 . 
rated $^{173}$ the California supreme court based the manufacturer's liability for injuries caused by a defective power tool on strict liability in tort rather than an implied warranty. Implicitly recognizing the importance to the public of the manufacturing enterprise, the court, speaking through Justice Traynor, referred to strict liability's origin in "the case of unwholesome food products" and noted that "sucl liability has now been extended to a variety of other products that create as great or greater hazards if defective."174 The court went on to observe that "[T]he recogmition that the lability is not assumed by agreement but imposed by law [citing cases] and the refusal to permit the inanufacturer to define the scope of its own responsibility for defective products [citing cases] make clear that the lability is not one governed by the law of contract warranties but by strict liability in tort."175 The obligation rests on the inanufacturer-consumer relationship alone: "Implicit in the machine's presence on the market, ... was a representation that it would safely do the jobs for which it was built."176

Observations of commentators and cases indicate that the doctrine of strict hability stems in major part from the belief that the ordinary consumer has the right to expect that the product will safely perform the operation whicl it undertakes and that the law should impose the obligation to do so. ${ }^{177}$ Strict liability reflects the fact that the "seller, by marketing his product for use and consumption, has undertaken and assumed a special responsibility toward any member of the consuming public who may be injured by it."178 The factors discussed in Henningsen are important only as forming the total context of the manufacturerconsumer relationship; the manufacturer's duty is not conditioned upon advertising to promote sales, but arises from "the mere presence of the product on the market."'179

Strict liability extends beyond the manufacturer to the distributor or the mercliandiser in the marketing chain whom the consumer would reasonably expect to bear the loss. ${ }^{180}$ The inanufacturer-assembler does

17359 Cal. 2d 57, 377 P.2d 897, 27 Cal. Rptr. 697 (1963).

174 Id. at 62,377 P.2d at 900,27 Cal. Rptr. at 700.

175 Id. at 63,377 P.2d at 901,27 Cal. Rptr. at 701.

176 Id. at 64,377 P.2d at 901,27 Cal. Rptr. at 701.

177 See, e.g., Putman v. Erie City Mfg. Co., 338 F.2d 911, 914 (5th Cir. 1964); Ford Motor Co. v. Mathis, 322 F.2d 267, 273-74 (5th Cir. 1963); Southland Milling Co. v. Vege Fat, Inc., 248 F. Supp. 482, 485-86 (E.D. Ill. 1965); Greeno v. Clark Equip. Co., 237 F. Supp. 427, 429, 431 (N.D. Ind. 1965) ; commentators cited in Putman v. Erie City Mfg. Co., supra at 920-21; commentators cited supra note 161 .

178 Restatencent (SECOND) OF ToRTS $\$ 402 \mathrm{~A}$, comment $c$ (1965).

179 Santor v. A \& M Karagheusian, Inc., 44 N.J. 52, 65, 207 A.2d 305, 312 (1965). See Rapson, supra note 161 .

180 Vandermark v. Ford Motor Co., 61 Cal. 2d 256, 391 P.2d 168, 37 Cal. Rptr. 896 (1964). 
not escape strict liability because damage resulted from a defect in a mechanical part incorporated in the completed product. ${ }^{181}$ Similarly, the manufacturer may be held vicariously liable for the negligence of the independent supplier. Thus, in Ford Motor Company v. Mathis ${ }^{182}$ the court sustained the car owner's action for damages for personal and property loss caused by a defective dimmer switcl which was manufactured by an independent supplier and which the defendant assembler placed in the car. The court held that the consumer would reasonably expect the inanufacturer-assembler to stand behind his product. The court stated: "The purchaser of a new automobile is led by the manufacturer-assembler to think that the car is a quality product. In effect, the purchaser does not distinguish between the assembler and the manufacturer." 183

The strict hability doctrine thus bears important resemblances to judicial treatment of contractual limitations in insurance contracts; in both situations many courts now reject the seller's attempted restriction of that quality of performance which the ordinary buyer may legitimately contemplate. In Greeno v. Clark Equipment Company ${ }^{184}$ the court pointed out the tort doctrine of strict liability: "... . is hardly more than what exists under implied warranty when stripped of the contract doctrines of privity, disclaimer, requirements of notice of defect, and limitation through inconsistencies with express warranties." 185 The court then proceeded to state that the "defective condition" on which liability is based is "a condition not contemplated by the consumer/user and whicli is 'unreasonably dangerous' to him or his property, that is, more dangerous than would be contemplated by the ordinary consumer/user with the ordinary knowledge of the community as to its characteristics and uses." 188

The product liability rule essentially rests upon the reasonable expectations doctrine: A consumer has the right to expect the safety of the vended product, an expectation that is known to the manufacturer. Recent interpretations of the strict liability doctrine demonstrate the im-

181 Id.; cf. Courtois v. General Motors Corp., 37 N.J. 525, 182 A.2d 545 (1962) (manufacturer liable for defective component on theory of breach of implied warranty). Most jurisdictions do not hold manufacturers strictly liable for defective components although they may be vicariously liable for the negligence of the component's supplier. Ford Motor Co. v. Mathis, 322 F.2d 267 (5th Cir. 1963); Markel v. Spencer, 5 App. Div. 2d 400, 171 N.Y.S.2d 770 (1958), af’d, 5 N.Y.2d 958, 157 N.E.2d 713, 184 N.Y.S.2d 835 (1959). See generally Annot., 3 A.L.R.3d 1016 (1965).

182322 F.2d 267 (5th Cir. 1963).

$183 \mathrm{Id}$. at 274.

184237 F. Supp. 427 (N.D. Ind. 1965).

$185 I d$. at 429 .

$180 I d$. 
portance of this basic concept. Thus, the California supreme court in Seely v. White Motor Company ${ }^{187}$ held that the doctrine could not be used to justify recovery for economic loss caused by a defect rendering a product unsuitable for a particular purpose. The court held that recovery for such loss must be governed by the Uniform Commercial Code. As one commentator has pointed out:

One suspects that the Cahifornia Supreme Court wished to establish a clear-cut category-economic loss-into which most claims surrounding just what expectations of quality and utility of a product were entertained by manufacturer and consumer would be placed. This category will be governed by the Uniform Commercial Code, a general plan designed to measure the reasonableness of these expectations. ${ }^{188}$

The products liability doctrine, paralleling the approacl of courts in other fields set forth above, derives liability from the relationslip of the parties rather than from the terms of the contract, and measures that liability by examining the nature of the expectations of the parties entering into the transaction.

\section{CONCLUSION}

In the preceding pages we have somewhat arbitrarily selected several fairly narrow areas of law to illustrate our hypothesis. That changes are taking place within each of these areas is clear enough; what is not so clear on the basis of traditional analysis is that these changes may be viewed as related to one another both functionally and doctrinally, and therein hes what we assert to be the value of our lypothesis. The functional relationship consists in the increased judicial sensitivity, explicit or implicit, to the role of the individual in today's integrated social order; the doctrinal relationslip consists in the judicial adaptation to that function, again often implicitly, of primciples rooted in early common law status concepts, particularly in the concept of a public service enterprise. Accepting the inevitability of large-scale production, these concepts protect the individual, as consumer, from the purveyor's disclaimer of hability for negligent conduct, and insure that the public service enterprise will provide those services which the average man can reasonably expect. Recognizing the importance of trade and professional organizations, courts may use these concepts to protect the individual as a producer, safeguarding his interest in becoming and remaining a member

18763 Cal. 2d 9, 403 P.2d 145, 45 Cal. Rptr. 17 (1965).

188 Comment, Manufacturer's Responsibility for Defective Products: Continuing Controversy over the Law to be Applied, 54 CALIF. L. REv. 1681, 1715-16 (1966). For a criticism of the court's approach in Seely, see Franklin, When Worlds Collide: Liability Theories and Disclaimers in Defective-Product Cases, 18 StaN. L. Rev. 974, 980-82, 1001-03 (1966). 
of such organizations and in participating in their affairs. Through the variety of factual situations, each of them requiring independent analysis and calling for unique solutions, run these common threads.

Recognition of the doctrinal roots which underhe these developments serves also to highlight the gradual and continuing nature of the process. Invocation of new concepts inevitably provokes questions as to the role of the courts in bringing about legal change, and properly so-concededly, there are himits to the judicial function. It is important, however, to remember that early status concepts were themselves primarily the product of judicial decision and that their gradual transformation represented judicial response to a then changing society; the common law has never been a body of static principles but a dynamic process. The great challenge to the legal system today is accommodation to the new industrial state. Rigid dependence upon legalistic concepts associated with nineteenth century society is as anachronistic for that purpose as is use of classical economic theory to explain the modern economy. ${ }^{189}$ The storehouse of the common law can and does supply the courts of today with the appropriate tools to meet the challenge.

189 See J. Galbratth, The New Industrial State 179-97 (1967). 